\title{
Complete loss of case and gender within two generations: evidence from Stamford Hill Hasidic Yiddish
}

\author{
Zoë Belk ${ }^{1} \cdot$ Lily Kahn $^{2} \cdot$ Kriszta Eszter Szendrői ${ }^{1}$
}

Received: 19 July 2018/Accepted: 18 December 2019/Published online: 23 November 2020

(C) The Author(s) 2020

\begin{abstract}
Yiddish was the everyday language spoken by most Central and East European Jews during the last millennium. As a result of the extreme loss of speakers during the Holocaust, subsequent geographic dispersal, and lack of institutional support, Yiddish is now an endangered language. Yet it continues to be a native and daily language for Haredi (strictly Orthodox) Jews, who live in close-knit communities worldwide. We have conducted the first study of the linguistic characteristics of the Yiddish spoken in the community in London's Stamford Hill. While Krogh (in: Aptroot, Aptroot et al. (eds.) Leket: Yiddish studies today, Düsseldorf University Press, Düsseldorf, pp 483-506, 2012), Assouline (in: Aptroot, Hansen (eds.) Yiddish language structures, De Gruyter Mouton, Berlin, pp 3962, 2014), and Sadock and Masor (J Jew Lang 6(1):89-110, 2018), investigating other Hasidic Yiddish-speaking communities, observe what they describe as morphological syncretism, in this paper we defend the claim that present-day Stamford Hill Hasidic Yiddish lacks morphological case and gender completely. We demonstrate that loss of morphological case and gender is the result of substantial language change over the course of two generations: while the case and gender system of the spoken medium was already beginning to undergo morphological syncretism and show some variation prior to World War II, case and gender distinctions were clearly present in the mental grammar of both Hasidic and nonHasidic speakers of the relevant Yiddish dialects at that stage. We conclude the paper by identifying some of the language-internal, sociolinguistic and historical factors that have contributed to such rapid and pervasive language change, and
\end{abstract}

Zoë Belk

zoe.belk@ucl.ac.uk

1 Department of Linguistics, UCL, London, UK

2 Department of Hebrew and Jewish Studies, UCL, London, UK 
compare the developments in Stamford Hill Hasidic Yiddish to those of minority German dialects in North America.

Keywords Yiddish · Hasidic Yiddish · Case · Gender · Language change · Morphological syncretism

\section{Introduction}

\subsection{Background}

Yiddish was the everyday language spoken by most Central and East European Jews during the last millennium. It is a Germanic language written in the Hebrew alphabet and containing significant Semitic (Hebrew and Aramaic) and (in the Eastern form, which comprises the basis of the modern language) Slavic lexical components and contact features. Traditionally Eastern Yiddish has three major dialect areas (Katz 1987, xxi; Jacobs 2005, 65; Weinreich 2007, 335): Northeastern (chiefly spoken in areas corresponding to present-day Lithuania, Latvia, and Belarus), Mideastern or Central (chiefly spoken in areas corresponding to presentday Poland and Hungary), and Southeastern (chiefly spoken in areas corresponding to much of present-day Ukraine and Romania). Yiddish also developed a standardised variety in the 1920s and 1930s based largely on the Northeastern dialect. While Yiddish had over ten million speakers before World War II, the Holocaust reduced these numbers drastically, compounded by the widespread migration and subsequent assimilation of Eastern European Jews to destinations such as North and South America, Western Europe, South Africa, Australia, and Ottoman and Mandate Palestine, as well as by state oppression in the former Soviet Union. As a result of this extreme loss of speakers, geographic dispersal, and lack of institutional support, Yiddish is now classified as a 'definitely endangered' language by UNESCO, is considered 'at risk' by the Endangered Languages Project (Catalogue of Endangered Languages 2018) and is recognised as a minority language afforded institutional protection by the European Union's European Charter for Regional or Minority Languages.

Yet Yiddish continues to be a native and daily language for Haredi (strictly Orthodox) Jewish communities. Haredi Jews form a close-knit society characterised by a strict interpretation of Orthodox Judaism and a very high level of family and community involvement. Most Yiddish-speaking Haredi Jews are adherents of Hasidism (Isaacs 1999, 12), a spiritual movement comprised of over a dozen subgroups following different rabbinic dynasties which trace themselves back to various geographic locations in Eastern Europe. The subgroups are usually named after these locations, for example, Satmar, Bobov, Ger, Vizhnitz, etc., most of which are located in the traditional Mideastern and Southeastern Yiddish dialect regions (with some exceptions, e.g., Chabad; see Sect. 2 for more details on dialectal 
differences). ${ }^{1}$ Accordingly, the Yiddish of Stamford Hill Hasidic speakers can be identified as descended from a Mideastern or Central variety (Mitchell 2006), as is the Yiddish spoken by Hasidic speakers in the New York area (Krogh 2012) and the Yiddish of many speakers in Israel (Assouline 2017).

There are currently an estimated 750,000 Hasidic Jews globally (Biale et al. 2018), with the largest communities located in Israel, mainly in Jerusalem and Bnei Brak; in the US, in the New York area; in Antwerp, Belgium; in Montreal, Quebec (Canada); and in London's Stamford Hill (ca. 40,000 people). Demographic studies of the communities are rare, and there is little documentation of their use of Yiddish. The few studies that exist all point to substantial Yiddish language use: for example, Holman and Holman (2002) claim that over $75 \%$ of adults and children in London's Stamford Hill community are 'fluent' in Yiddish, and over 50\% use it as 'the main language at home'; similarly, Isaacs $(1999,13)$, who studied the communities in the US, Belgium and Israel, claims that 'most Hasidim use Yiddish as a vernacular'. ${ }^{2}$

Considering that the vast majority of present-day Yiddish native speakers are Hasidic people, it is perhaps surprising that linguistic research into their speech practices is extremely scarce, and in the case of the Stamford Hill community, practically non-existent. This may simply be due to the fact that many scholars are unaware of the pervasive extent of Yiddish use in the Hasidic communities, or perhaps due to the degree of cultural divide between the Haredi and secular Yiddishist communities (see Nove 2018 for a strong and meticulously constructed position). Mitchell (2006) investigated the sociocultural context and institutional frameworks for Yiddish in the Stamford Hill and Manchester communities, but he offers almost no linguistic description. Assouline (2017) presents a similar study on language ideology and multilingualism in the Israeli Haredi communities. Krogh $(2012,2018)$ has studied the written language of Satmar Hasidim in the New York area, and Assouline (2014) has analysed certain aspects of the language of Israeli Hasidic Yiddish speakers. Sadock and Masor (2018) offer a basic description of Bobover Yiddish in New York. This paper is the first full report in our ongoing research project studying Hasidic Yiddish, and concentrates on the language of the Stamford Hill Hasidic community, with reference to preliminary data from other communities where relevant.

\subsection{Short summary and roadmap}

Our main finding is that present-day Yiddish as spoken by members of the Stamford Hill Hasidic community has lost morphological case and gender on full noun phrases. In poverty of case and gender morphology, our findings are similar to those of Krogh (2012), Assouline (2014), and Sadock and Masor (2018) for the Yiddish of other Hasidic communities. However, these authors interpret their findings as merely case syncretism, rather than loss of the notion of morphological case or

\footnotetext{
1 Some non-Hasidic Haredi Jews also speak Yiddish, but their numbers are smaller, and for many their language is based on the traditional Northeastern dialect; we have excluded them from the present study.

${ }^{2}$ In addition, Haredim often speak the majority languages of the respective countries and many have considerable knowledge of Hebrew and Aramaic. We return to this point in Sect. 5.2.
} 
gender from the mental grammar of these speakers. In addition to these findings, we demonstrate that the loss of morphological case and gender in full noun phrases is the result of substantial language change having taken place since World War II: while the case and gender system of the spoken medium was already beginning to undergo morphological syncretism and show some variation, morphological case and gender distinctions were clearly present in the mental grammar of both Hasidic and non-Hasidic speakers of the relevant Yiddish dialects before World War II.

While this paper focuses on the language of the Stamford Hill Hasidic community, our initial data from other Hasidic communities suggests that loss of morphological case and gender is a general feature in Hasidic Yiddish worldwide. Krogh's (2012), Assouline's (2014), and Sadock and Masor's (2018) findings are also consistent with this tentative conclusion. Beyond the evidence presented below, we leave the extent to which this pervasive change is a universal feature of Hasidic Yiddish to further research.

We bring a variety of evidence to support our claim. Section 2 provides an overview of the background to Stamford Hill Hasidic Yiddish and the methodology employed in our research. It includes an introductory discussion of case and gender in the historical Eastern European varieties of Yiddish and in Standard Yiddish, a description of the questionnaires and other materials used in our data collection, and an overview of the Yiddish speakers from Stamford Hill who participated in our study. Section 3 consists of an examination of morphological gender marking in the pre-War Yiddish of Hasidic and other speakers and writers, in comparison with that of contemporary Stamford Hill Hasidic Yiddish. Section 4 consists of an examination of morphological case marking in the pre-War Yiddish of Hasidic and other speakers and writers, in comparison with that of contemporary Stamford Hill Hasidic Yiddish. In Sect. 5, we note that such a rapid and pervasive loss of morphological case and gender marking on full nominals as has happened in (Stamford Hill) Hasidic Yiddish is extremely rare and provide some concluding remarks. These include a comparison of the developments in Hasidic Yiddish morphological case and gender with other minority Germanic varieties, a discussion of the potential causes of the pervasive language change observed in Stamford Hill (and other) Hasidic Yiddish, and a report on speakers' own perceptions of their language.

\section{Historical versus contemporary Yiddish: background information and materials}

Before turning to our discussion of case and gender in Stamford Hill Hasidic Yiddish, we will first provide some contextual background on nominal case and gender in the historical varieties of the language, as well as an overview of the methodology employed in our research. 


\subsection{Nominal case and gender in traditional Eastern Yiddish dialects and Standard Yiddish}

Eastern Yiddish has three major geographical dialects, Northeastern, Mideastern, and Southeastern, in addition to a standardised dialect called Standard Yiddish. Mideastern, Southeastern, and Standard Yiddish have tripartite nominal case and tripartite nominal gender systems consisting of a nominative, accusative, and dative case and masculine, feminine, and neuter gender marking on the definite article and attributive adjectives. This system is outlined in Table 1. It is directly inherited from the historical tripartite Germanic gender system (Jacobs 1990, 75). ${ }^{3}$

The tripartite gender system shown in the above table is primarily grammatical rather than semantic. Animate nouns do typically exhibit semantic gender marking, for example, der man 'the.MASC man' versus di froy 'the.FEM woman', but where inanimate nouns are concerned the gender marking is purely grammatical; similarly, diminutives typically exhibit neuter gender even when they have animate reference, for example, dos meydl 'the.NEUT girl', dos yingl 'the.NEUT boy'. In most instances the nouns themselves bear no easily identifiable morphological gender markers, with the exception of the ending $-e$, which generally denotes feminine gender. In the case of animate nouns, the semantic sense may override the ending, e.g. der tate 'the.MASC father' is masculine, despite the fact that the noun ends in the typically feminine marker $-e$. Case and gender are marked only in the singular. In the plural, all nouns take the same definite article $d i$ and all attributive adjectives take the suffix $-e$. In addition to the case markings on the definite article and adjectives, personal names and a small group of common nouns are marked with a dative suffix in all three genders and accusative suffix in the masculine, for example dem tatn 'the.ACC/ DAT father-ACC/DAT'. ${ }^{4}$

While in Standard Yiddish the case and gender system outlined above is generally rigourously adhered to, the traditional spoken dialects exhibit a degree of variation. Thus, in some local varieties the distinction between the accusative and

\footnotetext{
${ }^{3}$ Although Yiddish is written in the Hebrew alphabet, throughout the main text of this paper we present Yiddish data in YIVO romanization (YIVO 2019). Using a standardised system of romanization, rather than a phonetic transliteration, is a standard practice for research in syntax on languages that do not use the Latin alphabet. We chose the commonly used YIVO system, as it allows the reader to compare written and spoken data more easily, and to compare the novel data we present to data found in other sources. In particular, it is impossible to guess the phonetic realization of written material such as that found in the Tribune corpus and we therefore do not attempt to do so. The YIVO system is also designed to be intuitive to most readers of English.

However, we would like to emphasise that the Yiddish of the Stamford Hill community, and most Haredi communities worldwide, more closely approaches a Mid- or Southeastern dialect in terms of phonetic realization, which is not reflected in the YIVO system of romanization. As this article represents the first study of the language of the Stamford Hill community, we present for the sake of completeness all Yiddish examples in their original form (i.e. in the Hebrew alphabet for written examples, or a phonemic transcription for spoken examples), together with the YIVO romanization, a gloss and a translation in the Appendix.

${ }^{4}$ Northeastern Yiddish has a different system including only two genders, masculine and feminine, with no neuter. However, it resembles South- and Mideastern Yiddish in that it has three cases (nominative, accusative, and dative). See Wolf (1969, 116-29) and Jacobs (1990) for a detailed discussion of nominal gender in Northeastern Yiddish, which is not directly pertinent to the present study (as Stamford Hill Hasidic Yiddish is based largely on the Mideastern and Southeastern varieties).
} 
Table 1 Nominal case and gender marking in Standard Yiddish

\begin{tabular}{|c|c|c|c|}
\hline & NOM & $\mathrm{ACC}$ & DAT \\
\hline Masculine & der guter & \multicolumn{2}{|c|}{ dem $^{a}$ gutn } \\
\hline & 'the good' & & \\
\hline Feminine & & di gute & der guter \\
\hline $\begin{array}{c}\text { Neuter } \\
\text { (indefinite) }\end{array}$ & \multicolumn{3}{|c|}{$\begin{array}{l}\text { (a) gut } \\
\text { '(a) good' }\end{array}$} \\
\hline $\begin{array}{c}\text { Neuter } \\
\text { (definite) }\end{array}$ & & dos gute & dem $^{4}$ gutn \\
\hline Plural & \multicolumn{3}{|c|}{ di gute } \\
\hline
\end{tabular}

a The dem form of the determiner can be contracted with many preceding prepositions, resulting in forms such as oyfn 'on.the', mitn 'with.the' and farn 'before.the'

dative is not always strictly maintained (Weinreich 2007, 333-334). This has been observed in the language of Yiddish speakers who grew up in Eastern Europe before the War, as documented in the Language and Culture Atlas of Ashkenazic Jewry, an audio corpus made in the 1960s (see Wolf 1969, 129). For example, the phrase mit der alter bobe(n) 'with the old grandmother', in which the noun phrase appears in the dative as standard following a preposition, is attested as mit di alte bobe, with the noun phrase in the accusative, in certain varieties of Northeastern and Mideastern Yiddish (Wolf 1969, 130-131). Likewise, in some Northeastern and Mideastern dialect areas the dative can appear in contexts where the accusative would be expected, as in gedenk der alter bobe(n) 'remember the old grandmother' instead of the standard gedenk di alte bobe (Wolf 1969, 133-139). These variations seem to be more common with human than nonhuman nouns (Wolf 1969, 138).

Similarly, there are geographical fluctuations in grammatical noun gender, resulting in a common phenomenon whereby a given noun might be treated as either masculine or neuter by different speakers. For example, the noun veter 'weather' may be either masculine or neuter, whereas shtul 'chair' may be either masculine or feminine. Some of these variations are regional; for example, fus 'foot' is masculine in most varieties of Yiddish, but is feminine in Northeastern Yiddish (Jacobs 1990, 86). Similarly, noz 'nose' is feminine in most varieties of Yiddish, but masculine in Northeastern Yiddish (Jacobs 1990, 86). Note, however, that these phenomena do not seem to suggest a breakdown in the gender system in the pre-War traditional dialects, but rather simply regional variation in its use, with the biggest differences seen in the Northeastern dialect area. However, as already noted by Krogh (2012) in his study of the pre-war Satmar variety of spoken Yiddish, the tendency towards a merger of the accusative and dative in the feminine in southern Poland and Hungary may serve as a forerunner for the more extensive loss of case and gender seen in post-War Hasidic Yiddish, to be discussed below.

Feeding into the general issues of syncretisms in case and gender morphology is the fact that Polish Yiddish, a Mideastern variety, is characterised by phonological processes affecting word-final nasals and $/ \mathbf{b} /$, making their phonetic realization less distinctive. Given that much Yiddish case morphology makes use of word-final nasals and $/ \mathbf{b} /$, these processes are therefore prone to contributing to syncretisms in, 
and perhaps the eventual loss of, morphological of case and gender. Indeed, the discussion of pre-War Warsaw Yiddish in Sect. 3.1 will demonstrate that these processes neutralised several gender and case distinctions in the spoken language.

Be that as it may, while historical dialects of Yiddish vary somewhat in their realization of nominal case and gender, we will demonstrate in Sects. 3.1 and 4.1 that these varieties all maintained morphological distinctions between different grammatical cases and genders, as does Standard Yiddish. Our findings in Sects. 3.2 and 4.2 will demonstrate that the same cannot be said of Stamford Hill Hasidic Yiddish.

\subsection{Materials and methodology used in documenting historical varieties of Yiddish}

In establishing the status of morphological case and gender in the historical varieties of Yiddish that might have influenced contemporary Stamford Hill Hasidic Yiddish, we considered both Hasidic and non-Hasidic sources, and both written and spoken media. Our main sources are Sippure Ma'aśiyot, a collection of Hasidic tales published in 1815; recorded speeches of a number of Hasidic rebbes, or spiritual leaders, who were born in the late nineteenth and early twentieth centuries and recorded between the end of World War II and the mid-1980s; unpublished writings of a Vizhnitser Hasid, a native Yiddish speaker, born in 1923; and the recordings of native (non-Hasidic) Warsaw Yiddish speakers born in the early twentieth century documented in Geller (2001).

A piece of early written evidence for the use of case and gender in Hasidic Yiddish is Sippure Ma 'aśiyot, a collection of allegorical tales composed by the early Hasidic master Nahman of Braslav, who established the Braslav Hasidic group. Nahman was born and spent most of his life in eastern Poland and Ukraine and would have spoken a variety of Mideastern or Southeastern Yiddish. His tale collection was first published in a bilingual Hebrew-Yiddish edition in 1815 (Nahman of Braslav 1815). The examples from Sippure Ma'aśiyot appearing in this paper were sampled from tales 1, 2, 3, and 9 in the collection, a total corpus of 34 pages.

Most Hasidim who came of age in pre-War Eastern Europe were or are native speakers of Mideastern or Southeastern Yiddish, and their speech reflects the same tripartite case and gender systems as that of non-Hasidic speakers of Mideastern and Southeastern dialects and Standard Yiddish. The spoken use of nominal case and gender in pre-War spoken Mideastern and Southeastern Hasidic Yiddish is illustrated in the examples provided in the following sections, drawn from the recorded speeches of various Hasidic rebbes, or spiritual leaders. The full length of the recordings was explored for case and gender marking of nominals, with the examples provided representing the nominal case and gender systems of the speakers. The following three Hasidic rebbes are cited:

- Rabbi Naftali Tzvi Halberstam (1931-2005), rebbe of the Bobover Hasidic dynasty from 2000 to 2005. Rabbi Halberstam was born and raised in Poland. He 
spent a number of years in Israel in the 1940s before moving to New York near the end of the decade. The recordings were made in the US after World War II.

- Rabbi Yekutiel Yehudah Halberstam (1905-1994), the first rebbe of the SanzKlausenburg Hasidic dynasty. Rabbi Halberstam was born in Rudnik, Poland, and lived in Poland and Romania until the war. A survivor of Auschwitz, he eventually moved to New York and later Israel. The recordings were made in 1983.

- Rabbi Joel Teitelbaum (1887-1979), rebbe of the Satmar Hasidic dynasty. Rabbi Teitelbaum was born in Sziget, Hungary. He lived in various places in Hungary and Romania until World War II. Surviving the Holocaust, he emigrated to the United States in 1946, and remained there for the rest of his life. The recordings were made in 1950.

More recent evidence of nominal case and gender in written Hasidic Yiddish comes from the unpublished writings of a speaker who was born in 1923, a Vizhnitser Hasid who was raised in Maramureş (a region in northern Romania/ western Ukraine) and spoke a Mideastern variety of Yiddish from childhood. The representative examples were drawn from a randomly selected eight pages of a 69-page manuscript of narrative fiction and another randomly selected five pages from a second manuscript containing so-called gramen, rhyming text performed at community events such as weddings by the master of ceremonies, the badkhen.

Geller (2001) is a phonological study of Warsaw Yiddish. It includes nearly 200 pages of phonetically transcribed Warsaw Yiddish (mostly consisting of the informants' personal experiences during and immediately after the Holocaust), with side-by-side translations in Standard Yiddish, German, and Polish. The informants were born between 1909 and 1920 into non-Hasidic Yiddish-speaking families in Warsaw, and their parents were from Warsaw and the neighbouring area. This corpus provides a baseline for a dialect of non-Hasidic Yiddish that was coterritorial with the Yiddish of many of the Stamford Hill informants' grandparents and great-grandparents. For this study, pages of text were sampled at random from the corpus and all noun phrases with a definite article or attributive adjective on the sampled pages were added to a database until the database numbered approximately 200 items. As discussed in Sect. 2.1, either a definite article or an attributive adjective, in combination with the context of the noun phrase, is sufficient to identify case, gender, and number. This approach was used to ensure comparability with the Tribune corpus, discussed in the following subsection, and to get as wide a range of nouns as possible. However, it should be noted that the rates of errors to be expected in spoken and written material are different, with more errors expected in spoken language.

These four sources form the core of our historical baseline material. They provide evidence of the existence of case and gender in historical varieties of Yiddish spanning over 100 years in a variety of styles, media, and geographical locations. 


\subsection{Materials and methodology used in documenting Stamford Hill Hasidic Yiddish}

Our description of the status of case and gender in Stamford Hill Hasidic Yiddish is based on both published and elicited data. The published data is drawn from a weekly newspaper produced in Stamford Hill with a section written in Yiddish. We also developed a series of tasks to elicit both spoken and written data from native Stamford Hill Hasidic Yiddish speakers. Each of these is discussed briefly below.

Stamford Hill is home to the Jewish Tribune, a weekly English-language newspaper with a section written in Yiddish (the Yidishe Tribune). Unlike Der Yid and many other Yiddish-medium periodicals, most of which are published in New York, the Tribune is produced in Stamford Hill and is therefore representative of local Yiddish use. The Yidishe Tribune covers issues of international, national, and local importance. No information is available about the identity or even number of the journalists writing for the Yidishe Tribune, as bylines are not published. For the current study, we selected five articles at random from issues covering a four-month period (Jewish Tribune 2017a, b, c, d, e), representing a range of subject material and lengths. As with the Warsaw corpus, all noun phrases with a definite article or attributive adjective were added to a database totalling approximately 200 items. While they represent different media, the Warsaw and Tribune corpora allow for an objective point of comparison between the two varieties of Yiddish and provide the opportunity for more systematic quantitative analysis.

The remainder of the data was elicited from native Stamford Hill Hasidic Yiddish speakers in semi-structured interviews. Interviews were conducted in Yiddish and consisted of six separate tasks. Task 1 is a series of biographical questions on the informant's linguistic and cultural background, use of Yiddish in daily life, and attitudes towards the Yiddish language.

Task 2 is an online translation task consisting of short texts and dialogues written in English and controlled for case, gender, definiteness, animacy, and the presence of an attributive adjective. Informants are asked to read the texts sentence-bysentence quietly in English and translate them into Yiddish aloud. This task allows us to record the phonological realization of determiners and adjectival endings, along with various other aspects of the informant's syntax and phonology.

Task 3 is a Pictionary-style writing task, where informants are presented with 33 pictures relating to eight singular and three plural nouns in each of the three genders. Some of the nouns were drawn from the Swadesh list (Swadesh 1971, 283) while others were selected to be highly imageable, frequent, or from the Hebrew-Aramaic component of Yiddish. As Hebrew and Aramaic are both languages with morphological gender, we included nouns from this component to test whether speakers used the Hebrew/Aramaic gender in determining their Yiddish gender morphology. ${ }^{5}$ Each picture was accompanied with a 7 , the first letter of all versions

\footnotetext{
${ }^{5}$ Hebrew and Aramaic, known collectively as 'loshn-koydesh', form a sizeable stratum of Yiddish lexis. Hebrew and Aramaic have two morphological genders, masculine and feminine. In many cases, the gender of Hebrew/Aramaic lexical items in the original language and in Yiddish coincide, but there are a number of cases where the gender differs, usually favouring the phonological principles discussed in Sect. 2.1 or because they have been reanalyzed as neuter, which does not exist in Hebrew (e.g., the words
} 
of the definite article and representing the sound /d/, followed by a blank line, and informants were asked to fill in the blank by finishing the article and naming the object depicted in the image. This task is designed to prompt the informant to provide the 'dictionary' (nominative) form of each noun, to allow for analysis of gender morphology in the absence of competing considerations of morphological case.

Task 4 is a dictation task, where carrier sentences containing the same 33 nouns as in Task 3 are read out to the informant in Yiddish in each of the three cases, preceded by a definite article and accompanied by an attributive adjective. Informants are asked to "write down what they hear", with no further instruction given on the form of the definite article or morphological ending on the adjective. This task gives an indication of whether an informant varies the form of a single noun phrase according to its role in the sentence (i.e., with case morphology), and whether each informant is consistent in the gender morphology they attribute to each noun. Comparison with the answers provided in Task 3 allows for further insight into the consistency of gender morphology.

Task 5 is a copy-editing task. Informants are presented with a typed paragraph and asked to indicate anything that they would write or say differently, including word choice, spelling, sentence structure, etc. The basis of the text is a paragraph from the Yidishe Tribune, which originally included inconsistent case and gender marking. We adjusted the original paragraph to include roughly equal numbers of nouns in each of the three genders and cases, introduced morphological mismatches between determiner and adjective, balanced Standard-like and non-Standard-like forms, introduced nouns from the Hebrew-Aramaic component of Yiddish and added distractors in the form of spelling mistakes reflecting differing pronunciations. ${ }^{6}$ This task allows us to judge informants' attitudes to various morphological mismatches, in addition to their attitudes towards (non-)Standard-like case and gender morphology and spelling variants.

Task 6 is a forced-choice task, where informants are presented with the same 33 nouns as in Tasks 3 and 4 with all four determiners in subject, object and P-object positions (five determiners where the contracted preposition+determiner form is available). For each sentence, informants are asked to indicate which determiner(s) they find acceptable, find unacceptable, or are unsure about, along with correcting any other aspect of the sentence they feel is incorrect (e.g., spelling or word choice). In a language with morphological case or gender, such as German or French, informants would be expected to accept one correct determiner and reject the rest, but in a language without morphological case or gender, more variation or uncertainty would be expected. This task therefore gives a direct insight into

Footnote 5 continued

shabes 'Sabbath' and tales 'prayer shawl' are feminine in Hebrew but masculine in Yiddish. See Belk, Kahn, and Szendrōi (under review 1) for a discussion of the 'loshn koydesh' component of contemporary Hasidic Yiddish.

${ }^{6}$ We use the term 'Standard-like' to denote a system that is roughly in line with Standard Yiddish. Thus, the Yiddish of Nahman of Braslav's tales, with its tripartite case and tripartite gender systems is Standardlike, although the gender of individual nouns may differ in some cases from that of Standard Yiddish. Northeastern Yiddish is not Standard-like, as it only has two morphological genders. 
informants' knowledge of and attitudes towards morphological case and gender. Comparison with the answers provided in Tasks 3 and 4 allows for further analysis of informants' strategies in selecting determiner and adjective forms.

The tasks are presented to each informant in the order given above, in order to avoid influencing informants' answers as much as possible. Interviews often include periods of metalinguistic and sociolinguistic discussion, which also provide material for analysis.

\subsection{Stamford Hill Hasidic Yiddish participants}

Our description of Stamford Hill Hasidic Yiddish is based on interviews with 11 native Yiddish speakers (nine female, two male), all of whom were born and raised in Stamford Hill. They range in age from early 20s to around 50, with most being in their 20 s and 30s. They also represent a range of Hasidic groups, including Satmar, Vizhnitz, Belz, Bobov, and Slonim. Most of their parents were born in London, although the parental generation also includes people from the United States, New Zealand, Israel, and Iraq. The grandparental generation largely hails from Eastern Europe (including Poland, Hungary, Romania, and Galicia), but includes people from the United Kingdom, France, and Austria. Our research indicates that this type of mixed heritage is representative of the community in Stamford Hill and indeed many Hasidic communities worldwide.

All of our informants grew up speaking Yiddish in the home and were largely educated in Yiddish, especially in the early years. From high school on, it is usual for girls to be educated for half the day in Yiddish (in subjects of religious importance) and half the day in English (in subjects in which they will take secular national examinations). Boys attend khadorim between the ages of 3 and 13, where they study religious texts and laws in the original Hebrew and Aramaic; the main language of instruction is Yiddish. From age 13, boys attend yeshivas, high schools for religious training, where the curriculum focuses on the Babylonian Talmud, a monumental firstmillennium CE compendium of Jewish law and lore composed mainly in Aramaic with some Hebrew, and on later commentaries and legal texts written in medieval and early modern varieties of Hebrew. The informants' current use of Yiddish varies from occasional (when talking with one or both parents, for example) to everyday (when talking with their own children, as well as other family members and others in the community). Interviews were conducted in Yiddish, and all informants were comfortable conversing, reading, and writing in Yiddish. ${ }^{7}$ Most informants identified their own dialect of Yiddish as "Khsidishe (Hasidic) Yiddish", while others referred to "heymishe (homely) Yiddish" or "poshete (plain) Yiddish". None of the informants used a geographical term (e.g., "Polish", "Northeastern") to define their dialect.

The materials and methods discussed above will provide the basis of our comparison in Sects. 3 and 4 between Stamford Hill Hasidic Yiddish and earlier varieties, both Hasidic and non-Hasidic. We will demonstrate that, unlike the

\footnotetext{
7 To be clear, informants were not selected on the basis of their reading and writing skills. Rather, all the Stamford Hill Hasidic Yiddish speakers with whom we have been in contact have also been able to read and write in Yiddish, suggesting that literacy in the language is widespread.
} 
historical and Standard varieties of Yiddish, Stamford Hill Hasidic Yiddish lacks morphological gender and case in noun phrases.

\section{Loss of gender in Stamford Hill Hasidic Yiddish}

Our findings reveal the absence of morphological gender in both written and spoken Stamford Hill Hasidic Yiddish noun phrases. We demonstrate this development in the language by first discussing gender morphology in the historical written and spoken material outlined in Sect. 2, and comparing these results to findings from contemporary published and elicited Stamford Hill Hasidic Yiddish. Overall, we show that the historical written and spoken data provide evidence of consistent gender marking, while no gender marking is found in the spoken Stamford Hill Hasidic Yiddish data and inconsistent gender marking is found in elicited and published written Stamford Hill Hasidic Yiddish. To make the case for loss of morphological gender clear, we focus in this section on the nominative case, except where reference to other cases is relevant. However, our findings from the nominative case extend to both the accusative and dative.

\subsection{Morphological gender marking in historical written and spoken Yiddish}

In order to analyse potential developments in morphological gender in the nominal system of contemporary Stamford Hill Hasidic Yiddish, it is necessary first to investigate the morphological gender in the nominal system of earlier varieties of Yiddish. We establish a baseline for comparison by examining some of the earliest Yiddish spoken and written by Hasidic Jews. Dating back 200 years, Nahman of Braslav's tales provide relatively early evidence of written Hasidic Yiddish. ${ }^{8}$ Nahman established the Braslav Hasidic dynasty, and would have spoken a variety of Mideastern or Southeastern Yiddish. As demonstrated in the following examples and those discussed in Sect. 4, his writings contain a range of masculine, feminine, and neuter animate and inanimate nouns that appear with consistent gender morphology on the associated definite article and, where present, attributive adjective:

(1) Masculine nominative

\begin{tabular}{lllll}
\hline hot zikh der & keyser & gelozt af & der & velt \\
has REFL the.M.NOM emperor $(M)$ & let & into & the.F.DAT $\operatorname{world}(F)^{9}$ \\
'The emperor went out into the world.' & & (Nahman of Braslav 1815, 15)
\end{tabular}

\footnotetext{
${ }^{8}$ Israel ben Eliezer, known as the Baal Shem Tov 'Master of the Good Name', is regarded as the founder of the Hasidic movement. He lived in the first half of the eighteenth century.

${ }^{9}$ Standard Yiddish gender is provided for all relevant nouns in the glosses. Case and gender morphology is glossed according to the context: for example the dem determiner form, when associated with a masculine noun in an accusative context would be glossed as 'the.M.ACC'. In a nominative context, it would not be clear whether the case assignment was non-Standard or, perhaps, both case and gender assignment were non-Standard. Such an example might be glossed as the.M.ACC/DAT/N.DAT.
} 
(2) Feminine nominative

nokh dem hot di malke eyn kuk geton

after that.N.DAT has the.F.NOM queen $(F)$ one look made

'After that the queen took a look.'

(Nahman of Braslav 1815, 12)

(3) Neuter nominative

un es iz af zey mer nit geblibn, nor dos hemd

and it is on them more not remained except the.N.NOM $\operatorname{shirt}(N)$

'and nothing more remained on them, except their shirt'

(Nahman of Braslav 1815, 21)

The recorded speeches of the three Hasidic rebbes considered for this paper display similarly consistent morphological gender marking. The rebbes were born between 1887 and 1931 and spoke varieties of Mideastern and Southeastern Yiddish. Their speech therefore represents Hasidic Yiddish as spoken several generations after Nahman of Braslav, but at least one generation before World War II.

(4) Masculine nominative

a. er hot gevust az der kheyrem iz nisht gerekht he has known that the.м. NOM ban $(M)$ is not right

'He knew that the ban was wrong.' (N. T. Halberstam 07:28)

b. s'iz a shreklekher matsev

it.is a terrible-M.NOM situation(M)

'It's a terrible situation.'

(N. T. Halberstam 06:34)

(5) Feminine nominative

di shtot iz geven a misnagdishe shtot

the.F.NOM town $(F)$ is was a mitnaggedic-F.NOM town

'The town was a mitnaggedic ${ }^{10}$ town.'

(N.T. Halberstam 08:58)

(6) Neuter nominative/accusative

a. dos ershte mol

the.N.ACC first-N.ACC time(N) (Teitelbaum, track 1:1, 09:05)

'the first time'

b. a halb yor

a half.N.ACC year(N)

'half a year'

(Y. Y. Halberstam, track 10, 04:22)

$\overline{10}$ Anti-Hasidic Orthodox Jewish. 
Evidence of written Hasidic Yiddish, dating from approximately the same period, confirms the presence of consistent gender morphology. This written data comes from the unpublished notes of a Vizhnitser Hasid who was born in 1923 and was a native speaker of a Mideastern variety of Yiddish.

(7) Masculine nominative

a. der groyser khokhem

the.N.NOM great-N.NOM wise.man $(M)$

'the great wise man'

b. vos iz der groyser tuml?

what is the.N.NOM big-N.NOM commotion(M)

'What's the big commotion?'

(Cahan 1992, 64)

(8) Feminine nominative

dos iz far di eltern di greste skhoyre

that is for the.PL parents the.F.NOM biggest-F.NOM merchandise $(F)$

'That is the best thing the parents can want.'

(Cahan n.d., 3 15)

(9) Neuter nominative

in shtot iz gevorn a groys getuml

in town is became a big.N.NOM/ACC/DAT tumult( $(N)$

'There was a great tumult in [the] town.'

(Cahan 1992, 64)

Consistent gender marking is equally evident in the Warsaw corpus (Geller 2001), whose informants were teens and young adults at the start of World War II. The examples below demonstrate masculine, feminine, and neuter gender marking in the nominative case.

(10) Masculine nominative

der bruder iz geven a komunist

the.м.Nом brother(M) is been a communist

'My (lit: the) brother was a communist.'

(Geller 2001, 206-207)

(11) Feminine nominative

ven di milkhome iz aroys

when the.F.NOM/ACC $\operatorname{war}(F)$ is out

'when the war broke out'

(Geller 2001, 158-159) 
(12) a. Neuter nominative (definite)

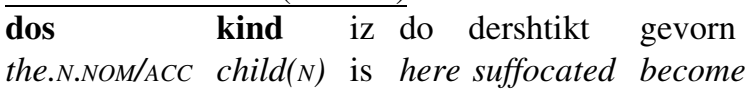

'My (lit: the) child was suffocated here.'

(Geller 2001, 306-307)

b. Neuter nominative (indefinite)

oystralye iz zeyer a sheyn

land

Australia is very a beautiful.N.IND country(N)

'Australia is a very beautiful country.'

(Geller 2001, 194-195)

As a large, phonetically transcribed corpus representing the Yiddish of people between one and three generations removed from our informants, the Warsaw corpus offers an excellent opportunity for quantitative analysis. Our sample included 200 noun phrases with a definite article or attributive adjective, 137 of which were singular. Of these singular noun phrases, 44 appeared in nominative contexts, including both animate and inanimate nouns. Only one of these phrases appeared with non-Standard gender morphology. ${ }^{11}$ These findings are summarised in Table 2. The headings 'der', 'di', 'dos', and 'dem' are shorthand for the der ...er (e.g., masculine nominative), di ...-e (e.g., feminine nominative), dos ...-e or $a \ldots-\varnothing$ (e.g., neuter nominative), and dem ...-em (e.g., masculine accusative) forms of the determiner and/or adjective. No phrases with mixed morphological agreement appear in the corpus. ${ }^{12}$

These results clearly show consistent marking of each of the three morphological genders in this dialect with both animate and inanimate nouns. Furthermore, grammatical gender assignment is in line with gender assignment in Standard Yiddish. No innovative usages of gender morphology (e.g., nominative use of dem ...-em forms) appear in the sample. The single instance of non-Standard gender morphology appears with a feminine animate noun, baleboste 'landlady', which appears in several other places in the sample with feminine morphology. Its appearance with masculine morphology in this example appears to be a speech error. Indeed, Luzzatti and de Bleser (1999), in a study on inflectional and derivational morphology in agrammatic Italian speakers, find gender morphology error rates of between 1 and $4 \%$ in the speech of their healthy native-speaker controls. Similarly, Schmid (2002) finds gender and case error rates of between 0.5 and $0.85 \%$ in the speech of L1 German speakers living in the United States, the Netherlands, and Canada (Schmid 2013, Fig. 5). The single error in the Warsaw sample sample, representing $2.3 \%$ of the total noun phrase tokens, is therefore in line with previous findings of gender error rates in spoken language. The findings for the nominative case are also in line with the accusative and dative: in each case

\footnotetext{
${ }^{11}$ Standard gender refers to the morphological gender that a given noun has in Standard Yiddish. We have determined the Standard gender of each noun based on its assignment in Beinfeld and Bochner (2013) and Finkel (n.d.). Where the two dictionaries differed, or offered more than one possible gender, we consider all available options as possible in Standard Yiddish.

${ }^{12}$ We use the term 'mixed (morphological) agreement' to refer to phrases where the determiner and attributive adjective (and, in the few cases where it is relevant, the noun itself) appear with conflicting case and gender morphology. Examples of mixed agreement are discussed in Sects. 3.2 and 4.
} 
Table 2 Morphological gender marking in nominative contexts in the Warsaw corpus

\begin{tabular}{lllll}
\hline Standard gender & der & $d i$ & $d o s$ & dem \\
\hline MASC $(\mathrm{n}=24)$ & $\mathbf{2 3}(\mathbf{9 6 \%})$ & 0 & 0 & 0 \\
FEM $(\mathrm{n}=9)$ & $1(4 \%)$ & $\mathbf{9}(\mathbf{1 0 0 \%})$ & 0 & 0 \\
NEUT $(\mathrm{n}=11)$ & 0 & 0 & $\mathbf{1 1}(\mathbf{1 0 0 \%})$ & 0 \\
& $=100 \%$ & $=100 \%$ & $=100 \%$ & \\
\hline
\end{tabular}

Forms coinciding with Standard Yiddish are in bold

we find consistent marking of each of the three morphological genders in both animate and inanimate nouns.

Overall, the data from historical sources, including Hasidic and non-Hasidic written and spoken texts, clearly indicates the presence of consistent gender marking on Yiddish definite determiners and attributive adjectives. These sources span 150 years and include the generation who acquired Yiddish shortly before the outbreak of World War II. In the following subsection, we will demonstrate that the Yiddish of Hasidic speakers who acquired the language in the last 20-50 years lacks consistent gender morphology, indicating that this development took place in the space of less than 50 years.

\subsection{Morphological gender marking in contemporary written and spoken Stamford Hill Hasidic Yiddish}

The data on morphological gender marking in contemporary Stamford Hill Hasidic Yiddish comes from three main sources: elicited spoken data, elicited written data, and published written data. The tasks discussed in Sect. 2.3 of most immediate relevance to the question of morphological gender marking are Tasks 1, 2, and 3 . Task 1 involves the participants answering questions on their personal and linguistic backgrounds, providing examples of relatively free speech. Task 2 is a translation task, where participants orally translate a text sentence-by-sentence from English into Yiddish. The text includes noun phrases counterbalanced for gender, case, definiteness, and presence of an attributive adjective. Task 3 is a fill-in-the-blank writing task where participants provide the citation form (i.e., in the nominative case) of 33 nouns depicted in illustrations, accompanied by the definite article. Tasks 4, 5, and 6 all involve the participants producing or considering multiple morphological cases. These latter tasks will not be the focus of this section, but will be discussed in detail in the following section. The results of these tasks will, however, be mentioned where relevant in this section. The final source of data on morphological gender marking in Stamford Hill Hasidic Yiddish comes from the Tribune corpus. As in the previous subsection, for clarity, we will focus here on the nominative case, although the results extend to the other cases.

The elicited spoken data from both Tasks 1 and 2 were consistent both within and across participants in their complete lack of morphological gender marking. In place of the traditional and Standard variants of the definite article in the nominative case, $d e r, d i$, and $d o s$, we uniformly find the innovative gender-less definite article $d e$. 
Table 3 Inflectional morphology in nominative contexts (elicited spoken data)

\begin{tabular}{llll}
\hline & Masculine & Feminine & Neuter \\
\hline Definite & & & \\
& de oreme man & de alte froy & de alte porfolk \\
& /də ureme man/ & /də alte fro:/ & /də alte purfolk/ \\
& the poor man & the old woman & the couple \\
Indefinite & & a freyləkhe mayse & a kurtse lebn \\
& a oreme man & /a fra:lexe ma:se/ & /a kirtse lerbn/ \\
& /a ureme man/ & a happy story & a short life \\
\hline
\end{tabular}

\footnotetext{
${ }^{a}$ Phonemic transcription is provided in the main text for this table and Table 7 only to give an indication of the phonetic character of the dialect. In general, the Yiddish letter $y$ ayen is realised as $/ \varepsilon /, / \partial /$ or even /e/ depending on a number of dialectal, phonological and phonetic considerations. In our broad phonological transcriptions, we abstract away from this distinction and use the character /e/ except for transcription of the Stamford Hill definite article de, which we transcribe as /də/. For all other examples of spoken data, phonemic transcription is provided in the Appendix.
}

Similarly, case and gender marking is absent on attributive adjectives where instead of the $-e r,-e$, and $-\varnothing$ endings, we find only $-e .{ }^{13}$ These results are exemplified in Table 3.

These data demonstrate that there is no difference in the inflectional morphology of the definite article or attributive adjective across the three traditional and Standard genders. We also find no difference between definite and indefinite nouns that are neuter gender in historical and Standard dialects: in spoken Stamford Hill Hasidic Yiddish, all definite determiners appear as de and all attributive adjectives appear with the $-e$ ending. These findings also hold of the accusative and dative cases.

It is important to note, however, that inflectional morphology is not absent from the noun phrase. Speakers have very strong intuitions about the adjectival $-e$ ending, requiring it on all attributive adjectives and disallowing it on predicative adjectives. This suggests that $-e$ is no longer a marker of case and gender agreement, but rather a marker of attributive modification. Note that this marker is either absent or nonobligatory on non-attributive categories that might agree with the noun in other languages (e.g., numerals, determiners). Thus, in contrast with the attributive adjectives in Table 3 , all of which require the attributive $-e$, the predicative adjectives in (13) disallow it.

\footnotetext{
${ }^{13}$ The phonetic realization of the $-e$ ending and, to a lesser extent, the definite determiner de varies between $/ \varepsilon /$ and $/ \partial /$. In normal speech, $d e$ is almost exclusively realised as $/ \mathrm{d} \partial /$, but in isolation can be realised as $/ \mathrm{d} \varepsilon /$.
} 
(13) a. De hoyz iz groys(*-e).

the house is big-ATTR

'The house is big.'

b Frayhayt iz vikhtig(*-e).

freedom is important-ATTR

'Freedom is important.'

This system of adjectival inflection is similar to that of Dutch, although the (non-) appearance of the so-called declensional schwa in Dutch follows a more complicated set of rules (see Kester 1996).

Gender morphology is consistently absent from spoken Stamford Hill Hasidic Yiddish, with the innovative definite determiner form de replacing earlier case- and gender-marked forms and the adjectival ending $-e$ being reanalysed as an attributive marker. However, de does not have an obvious equivalent among the written traditional and Standard definite determiners, der, di, dos, and dem. Furthermore, the absence of morphological gender distinctions in speech does not prove the absence of morphological gender in speakers' mental grammars: the spoken form de could simply be a phonetically reduced form of $d e r$ or $d i$, masking an underlying morphological gender distinction. We therefore asked speakers in Task 3 to provide written citation forms of 33 different easily imageable nouns, including nouns from the Hebrew/Aramaic component of Yiddish. If morphological gender were consistently marked in the written language, it would suggest that speakers have either implicit or explicit knowledge of both the concept of morphological gender and the gender of individual nouns. If morphological gender were not a component of their mental grammars, we would expect inconsistent marking of gender. Such inconsistency could take one of several forms: preferring the use of one written Standard determiner form over others, selecting determiner form on the basis of other (e.g., phonological) factors, using the various forms in free variation, or innovating a written determiner form to reflect the spoken determiner $d e$.

Words from the Hebrew component of Yiddish were included because both are languages with morphological gender, and all of our participants have at least some knowledge of pre-Modern and Modern Hebrew. ${ }^{14}$ We wanted to test whether Hebrew morphological gender had any influence on gender morphology in Yiddish.

Overall, we found that $50.5 \%$ of responses to Task 3 did not match Standard Yiddish gender. This result indicates that speakers do not consistently mark noun phrases for morphological gender. Two other major findings support this idea: the appearance of the Standard accusative/dative form dem in a significant proportion of responses, and the near-complete lack of $d o s$ forms. Dem is not found in the nominative case in any of the traditional or Standard dialects, where it is only used in objective cases and only with masculine (accusative and dative) and neuter (dative) nouns. The presence of nominative dem therefore represents a change in the grammatical status of this form of the determiner. The lack of $d o s$ forms represents a similar change: it appears to have

\footnotetext{
14 In-depth knowledge of Aramaic is less common among female participants, but this is irrelevant with respect to an investigation of morphological gender of nouns because the vast majority of Semitic nouns in Yiddish come from Hebrew rather than Aramaic, including all those used in our data.
} 
Table 4 Determiner use in nominative nouns in Task 3

\begin{tabular}{llllll}
\hline NOMINATIVE & der & di & dos & dem & \\
\hline MASC $(n=97)$ & $59(60.8 \%)$ & $23(23.7 \%)$ & $2(2 \%)$ & $13(13.4 \%)$ & $=100 \%$ \\
FEM $(n=87)$ & $56(64.4 \%)$ & $26(29.9 \%)$ & $1(1.1 \%)$ & $4(4.6 \%)$ & $=100 \%$ \\
NeUT $(n=41)$ & $19(46.3 \%)$ & $10(24.4 \%)$ & $4(9.8 \%)$ & $8(19.5 \%)$ & $=100 \%$ \\
ALL $(n=225)$ & $134(59.6 \%)$ & $59(26.2 \%)$ & $7(3.1 \%)$ & $25(11.1 \%)$ & $=100 \%$ \\
\hline
\end{tabular}

been reanalysed as exclusively a demonstrative pronoun. ${ }^{15,16}$ These findings also hold for words from the Hebrew component of Yiddish. See Belk et al. (under review 1) for more details on gender in the Hebrew component.

The results of Task 3 are summarised in Table 4 . The neuter determiner was almost never used: the proportion of nouns occurring with dos was 3.1\%. Rather participants select from masculine (der, dem) and feminine (di) forms. Assuming that only these three determiner forms are available to the participants would mean that they would perform at chance if they used each $33 \%$ of the time. A series of one-sample $t$-tests revealed that overall the form der was used marginally significantly more than as would be predicted by chance ( $p=.054, t=2.39, S E=12.63)$, while $d i$ forms were used marginally significantly less $(p=.053, t=0.67, S E=14.01)$, and dem forms significantly less than as predicted by a chance performance $(p=.018, t=3.24, S E=6.92)$. In other words, speakers do not use the various determiner forms at random: they underuse dem, marginally overuse $d e r$, and marginally underuse $d i$.

A series of one-sample $t$-tests revealed that the proportion of masculine forms used with the masculine nouns was not different from chance performance $(p=.14$, $S E=0.15)$. The same was true for the proportion of feminine forms used with feminine nouns $(p=.73, S E=0.18)$. Overall, these quantitative data indicate that the choice of determiner for this group of speakers was not determined by the gender of the noun in Standard Yiddish.

These quantitative results, however, obscure the strategies that individual participants adopted. Some participants chose one determiner form (usually der) to use for all examples. Others preferred one determiner form (either der or di for most examples), but used another form for a small minority or switched from favouring one form to favouring another part way through the task. Still others used the various forms in apparently free variation, including more than one example of dem being used with a plural noun. Furthermore, when comparing the results of Task 3 with those of Tasks 4 and 6, it is clear that, except where a participant uses one determiner form for all examples, a participant might write the same noun with different determiner forms in different sentences, even when it appears in the same morphological case.

\footnotetext{
15 While we do not focus on pronouns in this paper, we will note that the only examples of dos appearing in the Tribune corpus were demonstrative pronouns and not determiners.

16 While the Northeastern traditional dialect of Yiddish lacked the neuter gender, we do not believe that to be a significant influence on the lack of dos forms in written Stamford Hill Hasidic Yiddish. None of our informants reported having parents or grandparents from the geographical region covered by the Northeastern dialect, and the rest of their pronunciation does not reflect that of Northeastern Yiddish.
} 
These individual strategies go some way towards explaining the unexpectedly high rates of Standard-like gender marking, especially with masculine nouns. From discussion with participants, it was clear that many of them identified the written form der with the pronunciation de, and therefore wrote der where they would say de (i.e., for all nouns). These participants would therefore use der for $100 \%$ of the masculine nouns in the task. However, as they would also use der for $100 \%$ of the feminine and neuter nouns, this result does not indicate that they are aware of a distinct masculine form of the determiner. Indeed, overall der was used for a larger percentage of feminine nouns $(64.4 \%)$ than masculine nouns $(60.8 \%)$ and was the most common form used across all responses $(59.6 \%$ of all responses used $\mathrm{der}$, $26.2 \%$ used $d i, 3.1 \%$ used $d o s$, and $11.1 \%$ used $d e m$ ). Where free variation in determiner choice occurred, there was no indication that participants were using another conscious strategy (e.g., phonological patterning). Discussion with participants suggested that they were aware of the different written options for determiners and were choosing more or less at random.

The elicited written data represents the written language of non-professional writers in a relatively informal setting. All participants had been educated to at least high school level, with at least part of each day spent learning in Yiddish. The results of each task represent a snapshot of their linguistic behaviour. The Tribune corpus, on the other hand, provides a sample of professional writing in a relatively high, journalistic register, which has undergone some level of editorial scrutiny. This corpus is therefore likely to over-represent the actual grammatical knowledge of the writer(s): as long as one person in the editorial chain has a command of Standard-like morphological gender (whether native or acquired), the published article will represent this knowledge.

The Tribune corpus includes 197 noun phrases with either a definite determiner or an attributive adjective, of which 148 are singular. There were 34 noun phrases appearing in nominative contexts, 32 of which had identifiable gender. As with the elicited written data, neuter forms are severely underrepresented, with only two out of the 34 noun phrases appearing with nominative neuter morphology, whether definite or indefinite. (Only six out of the 148 noun phrases in the sample appear with neuter-specific morphology, such as the dos form of the definite article or an indefinite without the $-e$ ending on the attributive adjective. Three of these are in dative contexts and would therefore be expected to appear with dem forms.) Der and $d i$ forms are both found in the nominative case, along with one example of a noun phrase with dem. The quantitative results are summarised in Table 5.

Table 5 Morphological gender marking in the nominative case in the Tribune corpus

\begin{tabular}{lllll}
\hline NOMinAtive & der & dem & di & dos \\
\hline MASC $(n=19)$ & $\mathbf{1 6}(\mathbf{8 4 \%})$ & $1(100 \%)$ & $2(20 \%)$ & 0 \\
FEM $(n=11)$ & $3(16 \%)$ & 0 & $\mathbf{7}(\mathbf{7 0 \%})$ & $1(50 \%)$ \\
NeUt $(n=2)$ & 0 & 0 & $1(10 \%)$ & $\mathbf{1}(\mathbf{5 0 \%})$ \\
& $=100 \%$ & $=100 \%$ & $=100 \%$ & $=100 \%$ \\
\hline
\end{tabular}

Forms coinciding with Standard Yiddish are in bold 
While these results demonstrate a tendency towards use of der forms with masculine nouns and $d i$ forms with feminine nouns, the pattern is by no means consistent. Recall that speech error rates in gender morphology of between $0.5 \%$ and $4 \%$ can be expected in languages like Italian and German, even among firstgeneration heritage language speakers. In the Tribune corpus, a written corpus, fully $22 \%$ of noun phrases in nominative contexts appear with gender morphology that does not reflect the traditional or Standard gender of the head noun. Several individual nouns are used throughout the corpus with varying gender morphology. Furthermore, whereas no instances of mixed agreement patterns appeared in the Warsaw corpus out of 21 potential mismatch sites, one mismatch occurred in the Tribune corpus out of the five potential mismatch sites in the nominative case alone. These results are therefore not indicative of the presence of morphological gender in this variety of Yiddish, even in a high register with editorial oversight.

Our findings are illustrated by the examples below. (14) demonstrates two of the few examples of neuter agreement patterns in the sample. Shaykhes is a neuter noun in Standard Yiddish and here appears with a nominative neuter definite determiner. However, the attributive adjective eybiger, here appearing in an elision context, refers to shaykhes and thus would be expected to agree with it. Instead, it appears with masculine gender morphology.

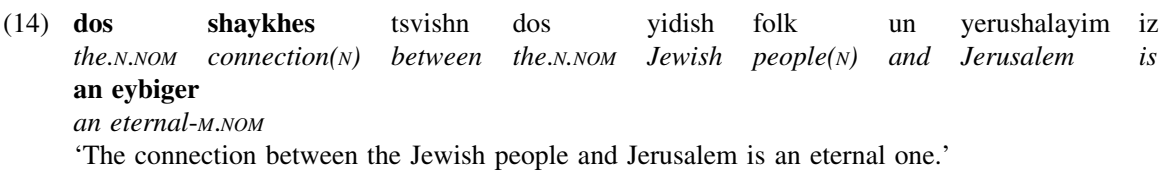

Jewish Tribune $2017 \mathrm{~b}$

(15a) demonstrates a noun that would be masculine in Standard Yiddish appearing with feminine morphology. (15b) demonstrates a noun that would be feminine in Standard Yiddish appearing with masculine morphology.
a. tsu farlaykhtern di
ekonomishe
tsushtand
to relieve the.F.NOM/ACC economic-F.NOM/ACC condition(M)
'to relieve the economic condition'
Jewish Tribune 2017b
b. der ershter opteylung iz geven ...
the.M.NOM first-M.NOM section $(F)$ is been
the first section was...
Jewish Tribune 2017a

Animate nouns behave in the same way. The corpus gives an example of a noun referring to a female, which is marked with an explicitly feminine suffix, appearing with masculine agreement on both the determiner and the adjective (16a). We also find a noun referring to a male (with the feminizing suffix absent) appearing with a determiner that could be feminine dative or masculine nominative and with feminine adjectival agreement (16b): 


$\begin{array}{llllllll}\text { (16) a. der } & \text { britisher } & \text { premier } & \text { ministorshe } & \text { terisa mey hot gelitn a } \\ \text { the.M.NOM } & \text { British-M.NOM } & \text { prime } & \text { minister-FEM } & \text { Theresa May has suffered a } \\ \text { niderlage } & \text { in } & \text { di } & \text { britishe } & \text { valn } & & \\ \text { defeat } & \text { in } & \text { the.PL } & \text { British-PL } & \text { elections } & & \end{array}$

'The British prime minister Theresa May has suffered a defeat in the British elections.'

b. lekoved der

ibergegebene menahel

in.honour.of the.M.NOM/F.DAT/ACC devoted-F.NOM director(M)

'in honour of the devoted director'

Jewish Tribune $2017 \mathrm{c}$

Jewish Tribune 2017e

Note that (16b) has mixed agreement whichever way the der form of the determiner is analysed. In Standard Yiddish, the noun phrase would be in the masculine dative, with the dem... $-(e) n / m$ endings. If the attested form of the determiner is taken to indicate dative case (as would be expected in this context), the gender of the noun phrase must be feminine. Alternatively, the der form of the determiner could be taken to indicate masculine gender, although this form is only expected in the nominative. In either case, the der form of the determiner mismatches the $-e$ adjectival ending, which is feminine nominative or accusative in Standard Yiddish and the historical dialects. In light of our findings in the spoken language, it is perhaps more likely that the morphology of (16b) reflects spoken language use. In that case, we could analyse the noun phrase as lacking case and gender marking entirely, with the $-e$ ending of the adjective representing a novel marker of attribution. The der form of the determiner would either reflect the semantically masculine gender of the referent or be the result of the near-chance use of $d e r$ versus $d i$. In a certain sense, the $d e r . . .-e$ 'mixed' agreement pattern can be thought of as a written form that is as close as possible to the spoken de ... - $e$ pattern found in singular noun phrases irrespective of gender and case. Arguably, $d i \ldots-e$ can also be thought of as a close approximation of the spoken forms, and thus any appearance of this form cannot be immediately taken to be evidence of Standardlike use of feminine gender marking in the nominative either. Nonetheless, the fact that even animate nouns do not consistently appear with appropriate gender agreement supports the idea that Stamford Hill Hasidic Yiddish does not realise morphological gender. Additionally, the presence of varying forms of adjectival morphology in the Tribune corpus, as opposed to the $-e$ ending that is uniformly found on attributive adjectives in the spoken language, suggests that speakers do not identify any one written form of the adjective with the pronunciation they use.

In our opinion, the most convincing piece of evidence that nouns in Stamford Hill Hasidic Yiddish lack gender comes from the fact that individual nouns appear in the corpus with different agreement patterns. Compare (16a) above with (17), (18a) with (18b), (19a) with (19b), and (20a) with (20b).

(17) britishe

premier ministorshe farlirt merhayt bay valn

British-F.NOM/ACC prime minister-F loses majority at elections

'British Prime Minister loses majority in election' Jewish Tribune 2017c 
(18) a. bay di koysel ha-marovi

at the.F.NOM/ACC wall(M) the-western

'at the Western Wall'

Jewish Tribune 2017b

b. tsum koysel ha-marovi

to.THE.M/N.DAT wall(M) the-western

'to the Western Wall'

Jewish Tribune 2017b

(19)
a. tsu efenen a groyse
to open a large-F.NOM/ACC
'to open a large celebration hall'

simkhe-zal

celebration-hall( $(M)$

b. a diner inem miryem rokhl vohl zal

a dinner in.the.M/N.DAT Miriam Rachel Wohl hall(м)

'a dinner in the Miriam Rachel Wohl Hall' Jewish Tribune 2017a

(20) a. di

gantse

hoyz numer 187 iz ibergearbet

the.F.NOM/ACC whole-F.NOM/ACC house(N) number 187 is over.worked gevorn

become

'the whole of house number 187 was remodelled' Jewish Tribune 2017a

b. hot men opgekoyft dem

have one up.bought the.M.ACC

'they bought up the nearby house'

\author{
dernebndign hoyz \\ nearby-M.ACC house( $N$ ) \\ Jewish Tribune 2017a
}

(20) is particularly interesting as hoyz 'house' is a neuter noun in Standard Yiddish, but it appears in the corpus with both feminine and masculine agreement and never with neuter. In general, the fact that these nouns appear with varying gender agreement patterns shows that it is not the case that nouns in Stamford Hill Hasidic Yiddish simply have different genders than their equivalents in Standard Yiddish. Rather, the agreement patterns they appear with seem to depend on factors other than their grammatical or semantic gender, or are used in free variation.

The Tribune corpus does not demonstrate consistent morphological gender marking. Although gender marking in nominative contexts in the corpus is Standard-like $78 \%$ of the time, compared to $49.5 \%$ in the elicited written data and $0 \%$ in the elicited spoken data, this rate is not indicative of a language with morphological gender. We have seen that in languages with morphological gender, errors in gender morphology can be expected to occur at a rate of between $0.5 \%$ and $4 \%$ in spoken language. However, as discussed earlier in this section, published written language like that represented in the Tribune is likely to over-represent the grammatical knowledge of its writers. Therefore, the fact that morphological gender marking in the Tribune corpus is non-Standard-like in $22 \%$ of the items indicates the absence of consistent morphological marking in the language.

On its own, the elicited spoken, elicited written and published written data discussed in this subsection demonstrate that grammatical gender is absent in 
Stamford Hill Hasidic Yiddish. However, the data discussed in Sect. 3.1 demonstrate that grammatical gender was present in the Yiddish of speakers who acquired the language as late as the 1920s and 1930s. This change therefore took place very rapidly, in the space of one or two generations. Furthermore, the change has not been to a system that looks identical to English, as the innovation of a distinct attributive marker indicates. In the next section, we will discuss the parallel absence of morphological case in Stamford Hill Hasidic Yiddish.

\section{Loss of morphological case in Stamford Hill Hasidic Yiddish noun phrases}

Standard Yiddish and most of the traditional dialects have three morphological cases: nominative, accusative, and dative. Data from Nahman's writings, recordings of rebbes speaking pre-War Yiddish, notes from a Vizhnitser Hasid who acquired Yiddish before World War II, and the material in the Warsaw corpus all confirm the presence of this tripartite case system. However, elicited spoken and written, and published written data from present-day Stamford Hill all fail to demonstrate consistent morphological case in noun phrases. ${ }^{17}$ This development from a language with morphological case to a language without morphological case appears to have occurred concurrently with the changes in morphological gender marking discussed in the previous section and represents a pervasive change to the nature of Yiddish speakers' mental grammars.

\subsection{Morphological case marking in historical written and spoken Yiddish}

As with the nominal gender morphology discussed in the previous section, we begin with a discussion of the historical baseline of written and spoken Yiddish used by Hasidim and others in the generations leading up to World War II. With respect to early examples of written Yiddish composed by Hasidim, the tales of Reb Nahman, dating from approximately 200 years ago, consistently demonstrate Standard-like morphological case marking: nominative, accusative, and dative cases are represented in each of the three morphological genders. The following examples demonstrate accusative and dative case marking in each of the three genders on definite articles and attributive adjectives; for nominative case marking, see (1-3):

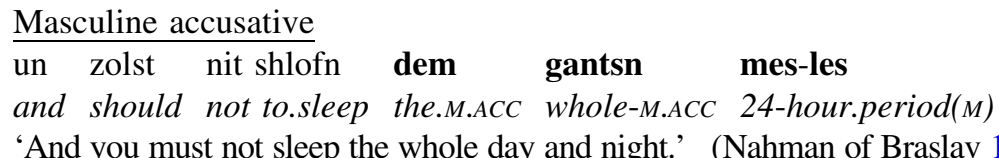

'And you must not sleep the whole day and night.' (Nahman of Braslav 1815, 12)

\footnotetext{
17 For reasons of space, we do not report on pronouns here, but see Belk et al. (in prep.). Morphological case has not completely disappeared from personal pronouns, although certain paradigm simplifications have also occurred in this domain. As is often the case, vestiges of a previously productive case marking system are still visible in some pronoun forms. The situation can be compared with English.
} 
(22) Masculine dative

hobn zey dos moydiye geven dem meylekh

have they the.N.NOM inform were the.M.DAT king(M)

'They informed the king of it.'

(Nahman of Braslav 1815, 11)

(23) Feminine accusative

hot er im dertseylt di gantse mayse

has he him told the.F.ACC whole-F.ACC story $(F)$

'So he told him the whole story.'

(Nahman of Braslav 1815, 13)

(24) Feminine dative

hot zikh der keyser gelozt af der velt

has refl the.м.NOM emperor let into the.F.DAT world(F)

'The emperor went out into the world.' (Nahman of Braslav 1815, 15)

(25) Neuter accusative

az er zol im vayzn dos ort

that he should him to.show the.N.ACC place(N)

'for him to show him the place' (Nahman of Braslav 1815, 64)

(26) Neuter dative

mit a kleyn shifl

with a small.N.DAT boat-DIM(M)

'with a small boat'

(Nahman of Braslav 1815, 18)

Recordings from Hasidic rebbes also demonstrate consistent marking of three morphological cases. The recordings represent Hasidic varieties of Yiddish acquired at the end of the nineteenth and beginning of the twentieth centuries. The following examples demonstrate masculine and feminine accusative and masculine, feminine, and neuter dative case marking; nominative and neuter accusative case marking are demonstrated in (4-6):

(27) Masculine accusative
a. haltn dem
yontef
to.keep the.M.ACC festival(M)
'to keep the festival'
b. tsu sheltn dem
to to.curse the.M.ACC
heylikn goen
holy-M.ACC Gaon(M)
'to curse the holy Gaon'
c. kh'veys du host a gantsn tog nisht gelernt
I.know you.SG have a whole-M.ACC day(м) not learnt
'I know you haven't studied [Torah] all day.'
(Teitelbaum, track 1:1, 04:03)

(Y. Y. Halberstam, track 6, 04:36) 
(28) Masculine dative

a. dos aleyn makht shoyn dem kesher fun eyn that.N.NOM alone makes already the.M.ACC connection(M) from one yid tsum andern

$\operatorname{Jew}(M)$ to.M.DAT other-M.DAT

'That alone is enough to make the connection from one Jew to the other.'

(Y. Y. Halberstam, track 10, 06:54)

b. oyfn gantsn guf

on.the.M.DAT whole-M.DAT body $($ M)

'on his (lit: the) whole body'

(N. T. Halberstam 11:30)

(29) Feminine accusative

hostu gemakht yede halbe sho

have.you made every-F.ACC half-F.ACC hour(F)

'you did [it] every half an hour' (Y. Y. Halberstam, track 6, 04:48)

(30) Feminine dative

me shloft oyf der erd, nisht oyf keyn bet

one sleeps on the.F.DAT ground(F), not on NEG bed

'they sleep on the ground, not in a bed' (Y. Y. Halberstam, track 2, 01:31)

(31) Neuter dative

mit a groys kol

with a big.N.DAT voice $(N)$

'with a loud voice'

(N. T. Halberstam 00:08)

Written material from the last generation to acquire Yiddish before the War also demonstrates consistent morphological case. Handwritten notes from a Vizhnitser Hasid born in the 1920s provide examples of nominative, accusative, and dative case marking in all three genders. Below we provide examples of accusative and dative marking in all three morphological genders. Nominative marking is demonstrated in (7-9) above.

(32) Masculine accusative

der koyfer nemt shnel dem oytser

the.м.Nом buyer(м) takes quickly the.м.ACC treasure(м)

'The buyer quickly takes the treasure.'

(Cahan 1992, 68) 
(33) Masculine dative

a. ruft zikh on eyner tsum tsveytn

calls REFL out one one-M.NOM to.M.DAT second-M.DAT

'One calls out to the other.'

(Cahan 1992, 65)

$\begin{array}{llll}\text { b. fun dem } & \text { fremdn } & \text { gast } \\ \text { from } & \text { the.M.DAT } & \text { strange-M.DAT } & \text { guest(M) }\end{array}$

'from the strange guest'

(Cahan 1992, 69)

(34) Feminine accusative

geyendik shoyn a lange tsayt tsu fus

going already a long-F.ACC time(F) on foot

'having walked on foot for a long time'

(Cahan 1992, 65)

(35) Feminine dative

in der groyser shul

in the.F.DAT big-F.DAT synagogue(F)

'in the big synagogue'

(Cahan 1992, 64)

(36) Neuter accusative

a. un men hot opgemakht dos gesheft

and one has made the.N.ACC deal $(\mathrm{N})$

'and they made the deal'

(Cahan 1992, 65)

b. men derlangt dir dos shenste

one gives you.DAT.SG the.N.ACC beautiful-most-N.ACC

un beste esn

and best-N.ACC food $(\mathrm{N})$

'They give you the most delicious and best food.' (Cahan 1992, 66)

(37) Neuter dative

a. in a halb yor

in a half.N.DAT year(N)

'in half a year'

(Cahan 1992, 65)

b. tsvey holtsheker fun a kleyn derfl

two woodcutter.PL from a small.N.DAT village(N)

'two woodcutters from a small village'

(Cahan 1992, 65)

The Warsaw corpus provides 137 examples of singular noun phrases with a definite determiner or an attributive adjective. Nouns of all three genders appear in nominative, accusative, and dative contexts, including both animate and inanimate nouns. Overall, the pattern is of Standard-like case marking in all three cases, with variable realization of the feminine dative. The results are summarised in Table 6.

There are no non-Standard forms, such as nominative dem, accusative der, or dative $d o s$. With the exception of the dative $d i$ forms, there are two tokens that do 


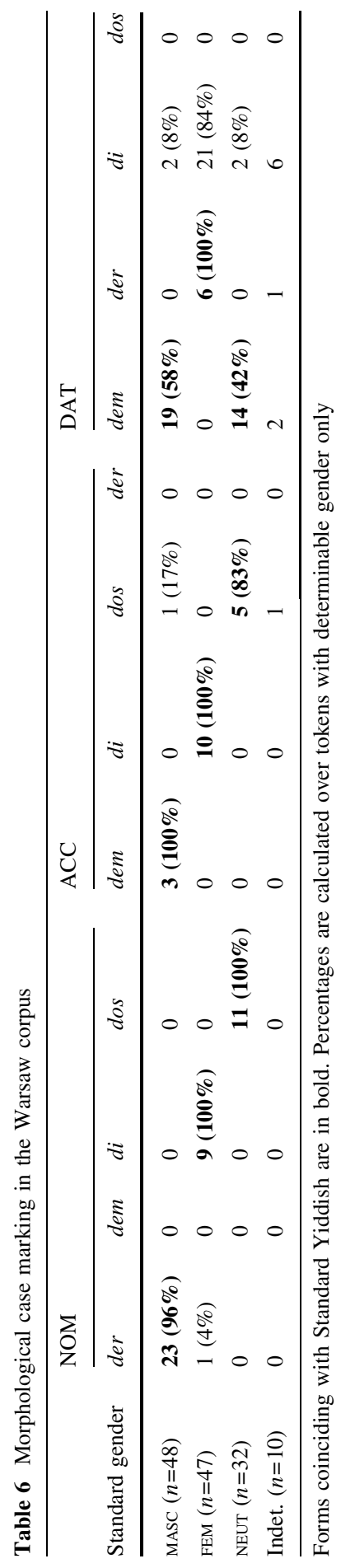


not coincide with Standard Yiddish in the sample. It is not clear how to analyse dative $d i$ : the tokens that appear with $d i$ morphology in the dative are overwhelmingly, but not exclusively, feminine nouns. However, feminine nouns are also realised with der morphology in the dative, and occasionally the same noun is realised with both $d i$ and der morphology by the same speaker, as in (38).

$$
\begin{aligned}
& \text { a. bay der nakht } \\
& \text { by the.F.DAT night } \\
& \text { 'at night' } \\
& \text { b. bay di nakht } \\
& \begin{array}{ll}
\text { by the.F.NOM/ACC night } \\
\text { 'at night' }
\end{array}
\end{aligned}
$$

(Geller 2001, 292-293)

(Geller 2001, 306-307)

One factor may be that word-final $/ \mathrm{r} /$ is usually vocalised or deleted in this dialect, meaning that $d e r$ is usually realised as $/ \mathrm{d} \varepsilon /$ and $d i$ as the minimally different $/ \mathrm{d} t /$. Part of this variation may therefore be due to the effects of speaking quickly or errors in transcription. However, given that a relatively large number of masculine and neuter tokens appear with dative $d i$ morphology compared to the error rates found in other cases (although in absolute terms their numbers are still small), it seems more likely to us that dative $d i$ represents the beginning or middle of a process of flattening of the gender paradigms in the dative case. In other words, there appears to be some gender syncretism in the dative case of these Warsaw Yiddish speakers, with dative di being available to a greater or lesser extent in all genders.

It is important to note, however, that this (optional) syncretism is not equivalent to the loss of case. Masculine and neuter nouns are still realised with distinct morphology in the nominative and accusative cases and almost always in the dative case as well. Feminine dative nouns are realised relatively frequently with Standardlike der morphology. The dative case is therefore distinct from both the nominative and accusative cases in all three genders in that it allows for variation where the other two do not. Of course, it is possible that this free variation is an early step in further case (and gender) syncretisms, which might eventually lead to a loss of morphological case (and/or gender). Nonetheless, it seems unlikely to us that this pattern of variation in the realization of the dative case is the only contributing factor to the total absence of morphological case and gender in Stamford Hill Hasidic Yiddish; possible causes of the developments in Stamford Hill Hasidic Yiddish are discussed in Sect. 5.

If $d i$ morphology is considered an optional realization of the dative case for all three genders, there are then two tokens in the sample that have case or gender errors, giving an error rate of $1.6 \%$. If $d i$ morphology is only optional for feminine nouns in the dative case, the two masculine and two neuter nouns appearing with it also constitute errors, which would give an error rate of $4.7 \%$. Both of these rates are consistent with speech error rates in case and gender morphology reported in the literature. 
While case and gender morphology is normally only realised on the definite article and attributive adjective in Standard Yiddish and the traditional dialects, there is a class of nouns that requires case morphology on the noun itself. Singular nouns denoting kinship terms (e.g., mame 'mother', tate 'father'), as well as proper names and a small number of other nouns (e.g., harts 'heart', yid 'Jew') take a $-n$ ending in the masculine accusative and in the dative in all three genders. Two such nouns appear in this sample of the Warsaw corpus, both of which appear with appropriate case morphology on the noun:
a. [ikh bin] gegangen mit di
with the.F.NOM/ACC/DAT stepmother(F).DAT
[I am] went with the.F.NOM/ACC
'I went with my (lit: the) stepmother).'
shtifmamen
(Geller 2001, 232-233)
b. me hot ge... skarzhet farn tatn
one has told.on
before.the.M.DAT
father(M).DAT
'Someone told on me to my (lit: the) father.' (Geller 2001, 234-235)

The Warsaw corpus also has a number of noun phrases with both an article and an attributive adjective, where case and gender morphology could potentially mismatch within the same noun phrase. Out of 21 potential mismatch sites, no actual mismatches occurred.

Overall, the historical data show consistent morphological marking of three distinct cases: nominative, accusative, and dative. This is true in both written and spoken language, in Hasidic and non-Hasidic speakers, and over a period spanning from the early nineteenth century (from a speaker who would have acquired Yiddish several decades earlier) to the last generation to acquire Yiddish before World War II. Pre-War Warsaw Yiddish shows some evidence of the beginning of gender syncretism in the dative case, but both the case and gender systems nonetheless appear robust in this dialect. In the next subsection we demonstrate that morphological case is not consistently realised in Stamford Hill Hasidic Yiddish, suggesting that morphological case does not exist in the mental grammars of Stamford Hill Hasidic Yiddish speakers.

\subsection{Morphological case marking in contemporary written and spoken Stamford Hill Hasidic Yiddish}

As with the evidence on lack of morphological case in Stamford Hill Hasidic Yiddish, in this section we consider three main sources of evidence: elicited spoken data, elicited written data, and published written data. Tasks 1 and 2 provide spontaneous and controlled spoken data, respectively, while Tasks 4, 5, and 6 provide data on how case and gender morphology are expressed in written Stamford Hill Hasidic Yiddish in the form of transcription of oral prompts, correction of a written text, and forced choice between competing forms of the definite determiner. Task 3, in which participants write the citation forms of a variety of nouns, provides a useful baseline. Published written data comes from the Tribune corpus. The overall pattern is twofold: spoken Stamford Hill Hasidic Yiddish lacks case 
Table 7 Absence of case morphology in spoken Stamford Hill Hasidic Yiddish

\begin{tabular}{|c|c|c|c|c|}
\hline & & Masculine & Feminine & Neuter \\
\hline \multirow[t]{8}{*}{ Definite } & \multirow[t]{3}{*}{ NOM } & de oreme man & de alte froy & de alte porfolk \\
\hline & & /de ureme man/ & /də alte fro:/ & /də alte purfolk/ \\
\hline & & the poor man & the old woman & the old couple \\
\hline & \multirow[t]{3}{*}{ ACC } & de oreme mentsh & de gute tsaytung & de beste fleysh \\
\hline & & /de ureme ment $\int /$ & /də gite tsaitung/ & /də bestə flai $\int /$ \\
\hline & & the poor person & the good newspaper & the best meat \\
\hline & \multirow[t]{2}{*}{ DAT } & mit de oreme man & oyf de tserisene shvartse kapote & nokh de shvartse sheyfele \\
\hline & & $\begin{array}{l}\text { /mit də ureme man/ } \\
\text { with the poor man }\end{array}$ & $\begin{array}{l}\text { /af də tserisene } \int \text { vartse kapote/ } \\
\text { at the torn black kapote } \\
\text { (type of coat) }\end{array}$ & $\begin{array}{l}\text { /no } \chi \text { də } \int \text { vartse } \int \text { arfele/ } \\
\text { after the black sheep }\end{array}$ \\
\hline \multirow[t]{9}{*}{ Indefinite } & \multirow[t]{3}{*}{ NOM } & a oreme man & a freylekhe mayse & a kurtse lebn \\
\hline & & /a ureme man/ & /a fra:le $\chi$ e ma:se/ & /a kurtse leıbn/ \\
\hline & & a poor man & a happy story & a short life \\
\hline & \multirow[t]{3}{*}{ ACC } & a naye hut & a gute besure & a alte shmutsige vayse hemd \\
\hline & & /a naie hit/ & /a gite bsire/ & /a alte $\int$ mitsige va:se hemed/ \\
\hline & & a new hat & a good message & an old dirty white shirt \\
\hline & \multirow[t]{3}{*}{ DAT } & oyfn lange veg & in a groyse mos & mit a breyte ofene harts \\
\hline & & /afn lange verg/ & /in a groise mus/ & /mit a brarte ofene harts/ \\
\hline & & on the long way & in a big size & with a wide open heart \\
\hline
\end{tabular}

morphology completely, while due to the lack of a non-morphologically marked determiner, written Stamford Hill Hasidic Yiddish uses inconsistent case morphology. This evidence combines to show that Stamford Hill Hasidic Yiddish speakers' mental grammars lack morphological case. ${ }^{18}$

As with our findings for gender morphology, the elicited spoken data gathered in Tasks 1 and 2 are consistent both within and across speakers in the complete lack of morphological case marking. These findings are exemplified in Table 7, which completes the paradigm provided in Table 3. The data are separated into cases according to the context of the sentence and into gender according to a Standard Yiddish dictionary (Beinfeld and Bochner 2013), but no difference in the form of either the definite determiner or attributive adjective is observed in any cell in the paradigm.

While Table 7 clearly demonstrates the absence of case morphology in spoken Stamford Hill Hasidic Yiddish, it equally clearly demonstrates the presence of the attributive modification marker $-e$, discussed in Sect. 3, on all attributive adjectives.

The total absence of case morphology in spoken Stamford Hill Hasidic Yiddish, however, does not rule out the possibility that speakers have some awareness of

\footnotetext{
18 As mentioned in fn. 17, pronominals do retain some case (and semantic gender) marking in Stamford Hill Hasidic Yiddish, although the system is somewhat simplified when compared to Standard Yiddish. However, the existence of separate pronominal case forms does not indicate that morphological case is active on full nominals. The situation can be compared to English.
} 
Table 8 Morphological case-marking patterns in the results of Task 4, a dictation task

\begin{tabular}{llllll}
\hline$n=346$ & $\begin{array}{l}\text { Standard case } \\
\text { marking }\end{array}$ & $\begin{array}{l}\text { Standard case, } \\
\text { nonstandard } \\
\text { gender }\end{array}$ & $\begin{array}{l}\text { Standard } \\
\text { gender, } \\
\text { nonstandard case }\end{array}$ & $\begin{array}{l}\text { Nonstandard } \\
\text { case, } \\
\text { nonstandard } \\
\text { gender }\end{array}$ & $\begin{array}{l}\text { Fully } \\
\text { innovative } \\
\text { forms compared } \\
\text { to Standard }\end{array}$ \\
\hline Mean & $12.3(22 \%)$ & $21.7(34.5 \%)$ & $6.3(11 \%)$ & $12.2(17.5 \%)$ & $7.2(15 \%)$ \\
Range & $7-20(14-34 \%)$ & $1-42(2.5-54 \%)$ & $3-10(7.5-13 \%)$ & $0-20(0-32 \%)$ & $0-28(0-68 \%)$ \\
\hline
\end{tabular}

morphological case. If remnants of morphological case existed in this variety, we might expect to see evidence of them in a more conservative medium than speech, such as writing. Standard and traditional varieties of Yiddish have no equivalent written form of the spoken Stamford Hill Hasidic definite determiner de, so we might expect Stamford Hill Hasidic Yiddish speakers, when writing, to select from among the four Standard and traditional definite determiners according to some knowledge of morphological case. To test this hypothesis, Task 4 requires participants to write down sentences that are presented to them orally. These sentences include the same 33 nouns as in Task 3 accompanied by a definite determiner and attributive adjective, with each noun appearing three times: in a nominative, accusative, and dative context. In addition, nine of the nouns were used in the plural. The resulting sentences were divided into three lists of 36 sentences each, with each participant completing one list. Each list had 3 feminine, 3 masculine, and 3 neuter singular nouns and 1 noun of each gender in the plural (with some overlap between lists). The sentences were read out by a native Stamford Hill Hasidic Yiddish-speaking research assistant, pronouncing the sentence as she would normally say it (i.e., with $d e$ as the definite article and $-e$ the attributive adjectival ending), and the participant was asked to 'write down what [they] heard'.

The results of Task 4 are very similar to Task 3, which were discussed in Sect. 3. Overall, participants gave answers corresponding to Standard Yiddish 22\% of the time. The remaining $78 \%$ of the forms were not fully or not at all conforming to Standard usage. A breakdown of these is provided in Table 8. 34.5\% of the responses involved forms that would correspond to Standard use of case marking, so long as non-Standard gender assignment is assumed, for example, if a speaker used der ...-er in the nominative case for a feminine or neuter noun. Another $11 \%$ of the responses showed the opposite pattern, with Standard gender assignment but nonStandard-like case marking, such as the use of der ... -er for a masculine noun in the accusative or dative. Yet another $17.5 \%$ could be interpreted as non-Standard-like use of both case and gender. In other words, these responses involved gender and case marking that would be available in Standard Yiddish, but the endings were used in a gender and case that would not be used in Standard Yiddish with that specific noun; this would include for instance the use of der -er for an accusative noun that is feminine in Standard Yiddish. Finally, 15\% of the forms used, with the range of responses as wide as $0 \%-68 \%$ across speakers, were fully innovative; that is, they constituted forms that do not exist in Standard Yiddish. This includes mismatch agreement forms, like der ...-e. 
However, the averages mask the different individual strategies that participants adopted. As with Task 3, some participants used one determiner across the board, while others used up to four determiners in seemingly free variation. For example, one participant used only $d i$...-e forms, resulting in answers that coincided with Standard Yiddish 32\% of the time and no forms that do not exist in Standard Yiddish. A second participant used mostly der ...-e forms, which are impossible in Standard Yiddish, $7 \%$ of the time, but in the sentences that involved no attributive adjectives nonetheless had answers that coincided with Standard Yiddish $34 \%$ of the time. Plurals were written as $d i \ldots-e$, der ...-e and even occasionally $d e m$...-e, underlining the idea that the link between the written $y-\ldots$ '. $d i \ldots-e$ forms and the spoken $/ \mathrm{d} \varepsilon \ldots-\varepsilon /$ forms has been broken. Again, the overall picture that emerges from Task 4 is the absence of consistent case marking, both across and within participants.

In Task 5, participants are given a printed paragraph in Yiddish that is derived from a paragraph that originally appeared in the Tribune. We edited the paragraph to ensure roughly equal numbers of noun phrases with Standard-like and non-Standard case and gender morphology, as well as a certain number of mismatches in the form of a definite determiner and its associated attributive adjective. The original paragraph included some instances of both Standard-like and non-Standard case and gender morphology, and care was taken to preserve original non-Standard morphology and counterbalance it with introduced non-Standard morphology, in case a pattern of which we were not aware existed in the use of non-Standard morphology. Distractor errors were introduced in the form of phonological spelling reflecting the prevailing accent in Stamford Hill (some of which also existed in the original paragraph), such as שיל shil instead of 'synagogue'. Participants were asked to read the paragraph and correct on the sheet anything that they personally would write or say differently.

If participants have an awareness of morphological case, we predict that they would correct the form of the determiner and attributive adjective in some way. If their morphological case and gender systems are Standard-like, as all of the historical varieties discussed in Sect. 4.1 are, we would expect them to correct determiners and adjectives to reflect a tripartite case and tripartite gender system. If the case paradigm has undergone some levelling, with novel syncretisms, we would expect participants to correct determiners and adjectives to reflect this simplified paradigm. If, on the other hand, participants are unaware of morphological case, we would expect them either to ignore the variation in determiner and adjective form, or to correct them to single unvarying forms across the board.

Participants overwhelmingly ignored determiner and adjective form when correcting the paragraph, focusing their corrections instead on spelling, vocabulary choice, and occasionally sentence structure. Where corrections to determiner or adjective do occur, it was usually to change the form of the attributive adjective to one ending in $-e$, even where such a change introduced a mismatch between determiner and adjective form. Even speakers who used one consistent form of the adjective and determiner in all answers for Tasks 3 and 4 did not correct the inconsistent case and gender morphology in Task 5. The results of this task therefore suggest that Stamford Hill Hasidic Yiddish speakers are unaware of 
morphological case and accept free variation in the form of definite determiners, but prefer attributive adjectives to end in $-e$. However, participants are familiar enough with spelling norms to correct most phonological spellings.

In Task 6, participants are given a series of sentences involving the same nouns as Tasks 3 and 4, with the nouns counterbalanced for case. As mentioned in Sect. 2, Task 6 is administered last, so as not to contaminate the results of the previous tasks. Each sentence is presented with each of the possible determiner forms (i.e., der, di, dos, dem, and for datives the form contracted with the preposition). The different options are presented side by side, and participants are asked to indicate for each option whether they would normally say the sentence that way; whether they might hear it but would not say it, or if they are unsure; or whether they would neither hear nor say the sentence and find it sounds bad. In a language with morphological case or gender, we would expect participants to accept only one option per sentence and reject the rest (with the exception of the contracted dative forms, which should be accepted alongside non-contracted forms), with a very low degree of uncertainty among such high-frequency nouns. If a language lacks morphological case and gender, we would expect a different approach: a higher degree of uncertainty, with participants accepting more than one option or not being sure which sounds right; free variation in the forms of the determiner participants accept; or one form being judged correct across the board (perhaps varying by participant).

All participants except one accepted or were unsure about multiple determiner forms for each set of sentences. These participants displayed a high degree of uncertainty about how they would write the definite determiner. In discussion with the experimenter, many expressed the idea that none of the options fit what they would say, which is de. In some cases it was clear that participants identified the pronunciation de with the spelling דער $d e r$, but nonetheless accepted or were unsure about other options. Most participants preferred the contracted form of the determiner and preposition in the dative, but accepted or were unsure about other options. Most participants rejected dos in all cases (possibly due to the fact that dos is phonologically much more distinct from de than the other forms of the definite determiner), but often accepted or were unsure about all of the other options. The one participant who only accepted one option per set accepted the contracted form when available and wrote in the novel form דע de, which is unmarked for case or gender, as the only acceptable option in the nominative and accusative cases. Overall, the results of Task 6 are indicative of a language that lacks both morphological case and gender in the nominal domain.

The final piece of evidence for the absence of morphological case in Stamford Hill Hasidic Yiddish comes from published written data in the Tribune corpus. The overall rates of morphological case marking within each Standard gender class are in Table 9.

We find that masculine nouns have Standard case marking $69 \%$ of the time, a number that is likely inflated by a general preference for der morphology. This number may seem high compared to what would be expected by chance performance, but it does not approach what would be expected in a language with morphological case. Korecky-Kröll and Dressler (2009) find that Jan, a child acquiring Austrian German, has correct determiner/adjective-noun agreement $72 \%$ 
Table 9 Morphological case marking in the Tribune corpus

\begin{tabular}{lllll}
\hline All genders & Standard case & Possible gender variant & Innovative & \\
\hline MASCULINE $(n=61)$ & $42(69 \%)$ & $11(18 \%)$ & $8(13 \%)$ & $=100 \%$ \\
FEMININE $(n=56)$ & $19(34 \%)$ & $7(12.5 \%)$ & $30(53.5 \%)$ & $=100 \%$ \\
NeUTER $(n=16)$ & $7(44 \%)$ & $4(25 \%)$ & $5(31.5 \%)$ & $=100 \%$ \\
\hline
\end{tabular}

of the time by the age of 2;7 (p. 288), a figure which will improve quickly as his grammar becomes more adult-like. Additionally, Bates et al. (1987) find that German-speaking Broca's and Wernicke's aphasics produce determiner substitution errors at a rate of $16 \%-17 \%$, far below the $31 \%$ seen in even masculine nouns in the Tribune corpus. While they do not provide figures for determiner substitution errors in their healthy controls, it is clear from their discussion that the healthy controls make many fewer substitutions.

More granular results are provided in Table 10. Compared to the Warsaw corpus data in Table 6, Table 10 demonstrates a much more random approach to case and gender morphology. While there are certainly tendencies towards Standard-like case and gender marking, they are relatively weak: Standard-like agreement morphology ranges from $19 \%$ in neuter dative nouns to $84 \%$ in masculine nominative nouns, both of which fall far short of the $95 \%+$ rates of correct usage found in German and Italian speech. Furthermore, as discussed in Sect. 3.2, the use of case morphology in published written form as in the Tribune is likely to over-represent the actual knowledge of the author, due to the editing process. Newspaper journalism represents a relatively high register and is therefore expected to adhere to formal grammatical standards more than actual colloquial speech.

The Tribune corpus additionally reveals a relatively large number of innovative usages of case and gender morphology, including nominative dem, accusative der, and dative dos, all of which were unattested in the Warsaw corpus:

a. dem tsveytn
the.M.ACC/DAT second-M.ACC/DAT

'The president gave his speech to the people on Tuesday.'

Jewish Tribune 2017b

In the Warsaw corpus, there were 21 instances where the determiner and adjectival morphology could mismatch, none of which actually resulted in a mismatch. In the Tribune corpus, however, there were 32 places where a mismatch could occur, and five of them were realised as mismatches (15.6\%). All mismatches involved an attributive adjective with the $-e$ ending. Examples include those in (41). 


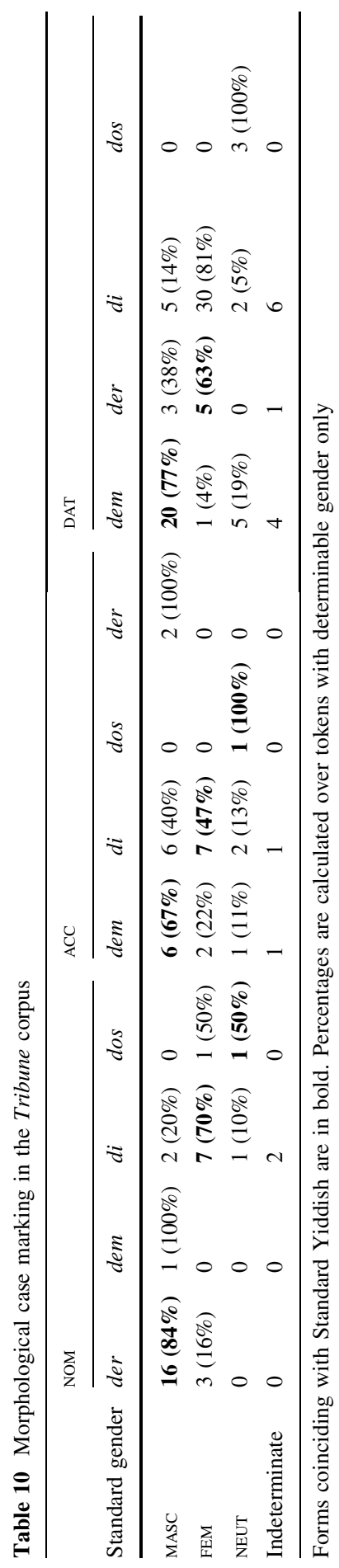


(41)
a. vert
gezen der
idishe
becomes seen
the.M.NOM
'the Jewish son-in-law can be seen'
b. oyf der linke zayt
on the.M.NOM left-F.NOM/ACC side(F)
'on the left side'

eydem

Jewish-F.NOM/ACC

son.in.law $(M)$

Jewish Tribune 2017b

Jewish Tribune 2017b

The overall picture that emerges from Stamford Hill Hasidic Yiddish is that morphological case is not consistently realised. The elicited spoken data reveal a complete absence of case morphology, while the elicited and published written data demonstrate inconsistent morphological case marking. The inconsistency in the written data compared to the consistent absence of case marking in the spoken data suggests that the written system is lagging behind the innovations of the spoken language. This is due to the lack of a non-case- and gender-marked definite determiner in written Stamford Hill Hasidic Yiddish, although there is evidence that דע de may be taking hold or that other determiners (usually דער der may be in the process of reanalysis as nongendered forms. In both the spoken and written language, however, the adjectival ending $-e$ has been reanalysed as a marker of attributive modification. This latter fact indicates that Stamford Hill Hasidic Yiddish has not undergone a 'loss' or 'degradation' in its grammatical system, but simply a development; Standard and historical varieties of Yiddish look more like German in their case and gender systems, while Stamford Hill Hasidic Yiddish looks more like Dutch (inasmuch as it has an attributive marker) or English (inasmuch as it demonstrates an absence of morphological case and gender). As demonstrated by the stark differences between the pre-War data discussed in Sect. 4.1 and the contemporary data discussed in Sect. 4.2, it is clear that this remarkable development has taken place in the space of fewer than three generations.

In the final section, we discuss parallel cases of language change, potential causes of the rapidity and pervasiveness of the developments seen in Stamford Hill Hasidic Yiddish, and speakers' attitudes to case and gender morphology in their language. We then summarise our findings.

\section{Concluding remarks}

\subsection{Comparisons with attrition in other Germanic varieties}

When considering the loss of morphological case and gender marking in Stamford Hill Hasidic Yiddish, it can be helpful to examine comparative data on other Germanic varieties. An instructive case is that of Pennsylvania German, which has some important parallels with Stamford Hill Hasidic Yiddish in that both languages are spoken by a close-knit minority community with a high degree of cultural and religious distinctiveness and separation from the surrounding society (in the case of Pennsylvania German, particularly with respect to the 'plain', or Amish and Mennonite, speakers), as well as a lack of state support or standardisation efforts. In addition, Pennsylvania German, like Hasidic Yiddish, is primarily an oral variety 
rather than a literary vehicle; speakers do not generally study the language's grammar explicitly in schools, and there is a high degree of bilingualism (see Stolberg 2015, 34-45 for details of the Pennsylvania German-speaking community). As such, examination of the extent of loss of gender and case in Pennsylvania German can provide a useful point of comparison to the absence of these features in Stamford Hill Hasidic Yiddish.

Stolberg (2015, 113-117) studied morphological gender and case in contemporary Pennsylvania German in comparison with earlier forms of the language going back over 100 years, based on a corpus of written texts published between 1868 and 1992 supplemented with spoken data (Stolberg 2015, 97). With respect to morphological gender, present-day Pennsylvania German differs strikingly from Stamford Hill Hasidic Yiddish in that it has retained all three genders (masculine, feminine, and neuter) inherited from Palatinate German, with the definite determiners for these genders realised as der, die, and es/'s respectively (Stolberg 2015 , 115). With respect to morphological case, there are also significant differences to Stamford Hill Hasidic Yiddish. While some case syncretism can be observed in present-day Pennsylvania German, this consists primarily of a merger between the nominative and accusative into a 'common' case, mostly in masculine and neuter nouns (Stolberg 2015, 115; see also Ferré 1991, 42-43). Huffines (1989, 223) and Ferré (1991, 42-43) also observe a tendency towards a merger with the dative, which would suggest a process of more extensive loss of case, though not of gender; moreover, the merger of the noun cases is not complete, as different common and dative forms are still sometimes used, particularly in the feminine and plural (Ferré 1991, 43). Thus, despite the sociolinguistic similarities between Pennsylvania German and Stamford Hill Hasidic Yiddish, with respect to morphological case and gender the former is very different from the latter, which has undergone a complete loss of both systems within a much shorter period.

Another instructive comparison can be drawn with Volga German spoken in the towns of Milberger and Russell in western Kansas by members (now in their 60s or older) of a community founded in 1876 by immigrants from the Volga region (Khramova 2011, iii). Like Pennsylvania German, so-called Milberger Volga German bears similarities with Stamford Hill Hasidic Yiddish in that it is a selfcontained community within a majority English-speaking environment. Milberger Volga German resembles Pennsylvania German in that the modern language has retained the traditional three genders, masculine, feminine, and neuter, with the definite determiners realised as der, die, and des (Khramova 2011, 58-59). There is some syncretism between the masculine and feminine determiners, which can both be realised as a weakened variant $d e$, but this does not constitute loss of gender as the weakened variant is only sometimes attested and the three genders are commonly distinguished morphologically (Khramova 2011, 59-60). Likewise, Milberger Volga German exhibits only partial case syncretism, having lost its historical genitive form but retaining nominative, accusative, and dative cases which are marked on the definite determiner with occasional merging of the accusative and dative with masculine nouns (Khramova 2011, 59-64). There are also distinct attributive adjective endings for the different genders and cases when there is no definite determiner (Khramova 2011, 66), though, like Stamford Hill Hasidic 
Yiddish, these are reduced, often to $-e$ but with some variations, when appearing in conjunction with a definite determiner (Khramova 2011, 64-65). Thus, Volga German in western Kansas, like Pennsylvania German, seems to have undergone partial case simplification over the course of a much longer period than that in which Stamford Hill Hasidic Yiddish has undergone complete loss of morphological gender and case.

A closer parallel with the Stamford Hill Hasidic Yiddish situation may be drawn with the historical loss of morphological gender and case in English between the Old English and Middle English periods. There is debate regarding the length of time over which this development occurred, with some arguing that it was rapid and the result of a creolisation process (see, e.g., Wallmannsberger 1988 for discussion), while there have also been counter-arguments that it was slower (see Allen 1997). The lack of spoken data for the period in which the shift occurred makes it difficult to establish the rate of change with certainty. The change in English has resulted in a system which is very similar to that of contemporary Stamford Hill Hasidic Yiddish (with the exception of the use of the attributive marker $-e$ in the latter), but its emergence is likely to have taken considerably longer than 70 years.

Thus, comparison with other minority Germanic varieties in bilingual situations does not reveal a counterpart to the rapid and total loss of morphological gender and case seen in Stamford Hill Hasidic Yiddish. Historically, the example of English in the medieval period may be a closer parallel, but the pace of the change in English is more difficult to establish. The evidence therefore points to a fairly unique case of rapid and pervasive grammatical change in Yiddish in the post-Holocaust period.

\subsection{Potential causes of the developments in the case and gender systems of Stamford Hill Hasidic Yiddish}

Given the pervasiveness and the perhaps unprecedented rapidity of the process, we have no doubt that the reasons for how and why this change took place must be multifactorial. We have identified a set of factors that are potentially relevant, which are enumerated below.

In the pre-World War II context, Yiddish was spoken in a trans-national area with a vast geographical spread, a situation that persisted over several centuries. As a result, it is not surprising that many mutually intelligible but nevertheless phonologically and to some extent grammatically distinct spoken dialects arose. Unlike the situation before the Holocaust, present-day Hasidic sub-communities trace their roots back to wide geographical areas and have included waves of second-language Yiddish speakers. Thus present-day Hasidic speakers learnt their mother tongue from speakers of a variety of spoken dialects. Such koiné situations are known to adversely affect morphological paradigms (Trudgill 1986). Some of the spoken dialects, in particular the spoken Mideastern dialects, already exhibited limited instances of case and gender distinction neutralisation pre-World War II. For example, Polish Yiddish is characterised by phonological processes that delete word-final nasals and /r/, neutralising many of the gender and case distinctions. The Polish and Hungarian dialects form the ancestor dialects of the majority of Hasidic speakers, given that Hasidism originated in Galicia (present day Poland and 
Ukraine). In fact, some scholars have argued that the process of loss of case had already started before the War, and manifested itself in morphological syncretisms in the pre-World War II spoken Unterland (Galician) Central Yiddish (Krogh 2012, 495).

However, if there was a single most important factor that propelled the change that started out as morphological case syncretism into full-blown absence of morphological case and gender from the mental grammar of Stamford Hill Hasidic Yiddish speakers, it was the Holocaust. Due to the catastrophic loss of speakers and the disintegration of Eastern European communities, Hasidic Yiddish has essentially developed in a vacuum for the past 70 years: having been the cultural cornerstone of the socially and religiously diverse body of Central and Eastern European Jews prior to World War II, Yiddish now functions as a vernacular predominantly only in Hasidic communities. This linguistic diaspora is somewhat akin to a heritage language situation, which is known to result in grammatical attrition in the language both in terms of morphology (specifically case morphology, as discussed in Isurin and Ivanova-Sullivan 2008, and gender agreement, as discussed in Polinsky 2008), and also in syntax (Polinsky 2011). Nevertheless, the level of attrition is usually much more restricted in heritage language situations, as demonstrated by MartinezGibson (2011), among others, who investigates gender agreement errors in heritage and L2 Spanish speakers, with error rates an order of magnitude smaller. Heritage language situations generally do not lead to full reorganisation and reanalysis of entire morphological case and gender paradigms.

A further factor that is likely to have contributed to the acceleration of this process of change is that Hasidic speakers by and large choose to ignore the vast body of non-Hasidic Yiddish-medium literature and nonfiction writings, considering such writings incompatible with the Hasidic lifestyle. For this reason, the written language cannot exert its general tendency of preservation and counteracting language change. By contrast, although pre-World War II Polish Yiddish speakers may have neutralised some case distinction in their everyday speech, they would certainly have been able to apply the full case paradigm in their writing as schooling, literature, newspapers, and other forms of culture would have provided knowledge of the case and gender system. After World War II this tradition was broken, and although Yiddish-language schooling is on the rise in many Hasidic communities, and newspapers and other forms of culture are increasingly available in Yiddish, nevertheless present-day Hasidic speakers do not have contact with models of consistent morphological case and gender marking.

A related factor is that Yiddish does not have a high prestige in Hasidic communities in the sense that it is considered far more important to develop a sophisticated knowledge of pre-modern Hebrew and Aramaic for religious study than to better one's Yiddish competence and eloquence. This is compounded by the fact that explicit grammatical instruction is generally not a priority in the traditional Hasidic educational model; indeed, in some cases, as in that of the Satmar community, Yiddish grammatical instruction was specifically discouraged by the Rebbe as he regarded the study of grammar as an element of the world of secular Yiddishists. As a result, explicit Yiddish language education in schools is limited, and strict editorial standards of written Yiddish publications are rarely maintained. 
However, over the last decade or two, there has been an increasing interest and pride in the Yiddish language in Hasidic communities and a noticeable increase in literacy and grammar education as well as a continuous rise in schooling using Yiddish as a medium in many Hasidic and non-Hasidic Haredi groups.

Finally, not unlike pre-War Yiddish speaking communities, present-day Hasidic communities worldwide are characterised by a high degree of multilingualism. Most Hasidic speakers in the Stamford Hill Hasidic community and the communities in the US are also speakers of English; speakers in Montreal largely also speak English, with some knowledge of French especially among women; Antwerp speakers predominantly speak French and Flemish in addition to Yiddish; and most Yiddish Hasidic speakers in Israel also speak Modern Hebrew. In addition, there is a very high level of cross-community marriages: according to Holman and Holman (2002, 29, Tables 4.8-4.9) 23\% of married children of the surveyed households in the Stamford Hill Hasidic community live in Israel while $22 \%$ of spouses of married children currently living in the Stamford Hill Hasidic community were born in Israel, and because of the generally high prestige of the Israeli communities, many Hasidic speakers of Yiddish worldwide also speak Modern Hebrew. Finally, all Hasidic people, but especially men, would have substantial knowledge of premodern Hebrew and Aramaic, due to their religious practices. This multilingual existence gives rise to typical features of multilingual communities including different degrees of code switching and borrowing.

Multilingualism also raises the potential possibility of transfer of grammatical features from one language to the other (see for instance Kahn 2009, 2015; Doron and Meir 2015 on transfer from Yiddish to Hebrew). Specifically, in the context of loss of case and gender marking, the question arises whether this could have been due to interaction with, or transfer from, English. Given data from Antwerp, Montreal, and Israel suggesting morphological case and gender are also absent in the Yiddish of Hasidic communities there, our initial hypothesis is that this is unlikely to be the case. Modern Hebrew, French, and Flemish lack case but all have gender. So, if transfer were the cause of the loss of case and gender in English, we would expect a differential outcome in the Yiddish of the communities in the English-speaking countries versus the Yiddish of the other communities. We have no evidence available to us that supports the presence of such differential behaviour in this domain, whereas evidence does exist that morphological case and gender marking is remarkably consistent across these communities (but see Assouline 2019 for persuasive instances of transfer of some more specific constructions). Finally, as Krogh (2018) also notes, the innovative use of the $-e$ attributive adjectival ending has no equivalent in English.

Nevertheless, the multilingual setting in which present-day Hasidic Yiddish speakers live their lives is important for a more general reason. Multilingual speakers often have different levels of language competence in their respective languages. We have certainly found evidence of high levels of variation in the ease or comfort of expressing oneself in Yiddish in speakers within the Stamford Hill Hasidic community, with for instance Satmar Hasidic speakers generally using Yiddish more frequently than Gerers in their daily lives, and men generally using it more frequently than women. We have also noted that there seems to be a high 
proportion of speakers of Yiddish in the Stamford Hill Hasidic community that are not native speakers of the language, but advanced second language speakers. A large number of non-native Yiddish speakers entered the Hasidic communities immediately after the Holocaust, as well as in later waves in the 1970s, 1980s, and later. This change in demographics could well have been another important factor in propelling the change to complete absence of morphological case and gender in the sense that a large enough influx of L2 speakers can exert a partial creolization effect resulting in grammatical simplifications and other linguistic changes. The comparison with Pennsylvania German and Volga German further underlines the importance of this factor. All of these languages had a lengthy existence as a minority language spoken as a vernacular, rather than a literary medium, in a multilingual setting. However, the important difference between these varieties and Hasidic Yiddish is that their transmission was not broken by a calamity like the Holocaust, the ensuing migration and mixing of the community of speakers, and a large influx of second language speakers, all within the space of a generation or two.

In this subsection we have enumerated a set of potentially relevant historical facts and sociolinguistic factors that are likely to have contributed to the current absence of morphological case and gender in Stamford Hill Hasidic Yiddish, and Hasidic Yiddish more generally. In the future, we intend to study these factors more closely and hope to be able to explain more comprehensively how and why a language can undergo such rapid and pervasive change. For now, we conclude that the sociolinguistic character of Yiddish is highly unusual and many factors have plausibly contributed to the process. The crucial causal factor in this process appears to be the destructive effect of the Holocaust on the speaker community and on the transmission of the language.

\subsection{Speakers' own perceptions}

Having examined the data concerning our Stamford Hill Hasidic Yiddish-speaking informants' morphological case and gender, it can be instructive to consider what they themselves thought of this topic. All of our informants knew about the idea that Yiddish uses "the der, di, dos". Despite almost never using any of these in their speech, some informants insisted that "khsidishe yidish" 19 has rules about determiner use in writing. However, they were often unable to say what the rule was. Some thought male animates (i.e., semantically masculine) take der, while females and plurals take $d i$. They were less sure about $d o s$. Several informants stated that there is a system, for instance in well-edited books, but that they were "unable to pick up the proper pattern" and that they were never taught it. Some male informants thought that girls were taught more grammar than boys, while at the same time some female informants thought that boys were taught much more Yiddish grammar than girls. One female speaker commented, "der, di, de - no idea!" Another remarked that she had "learnt about der and di in school", but that

\footnotetext{
19 "Khsidishe yidish" is the term many speakers use for their own language when asked what kind of Yiddish they speak. This expression reflects the Hasidic use of $-e$ as an attributive adjective marker (cf. Standard Yiddish, in which the phrase would be khsidish yidish).
} 
she did not remember what she had learnt. Some speakers noted explicitly that there is no difference in speech in the definite determiners: one stated that "when you speak Yiddish, you can't hear that kind of difference - you say de mentsh [the person]; it could be $d e r$, it could be $d i$ ". Others expressed a preference for certain forms in speech, but the preference was not based on Standard-like gender and case rules; for example, one speaker said, "I never say di or dos - I say de [referring to the spelling דער der] or dem".

We have also seen a textbook aimed at primary school girls in one of the schools in the Stamford Hill community, which claims that der should be used for bigger objects, while dos should be used for smaller objects (Hotsa' at Chay 1999, 33). This formulation of the rule presumably has its origins in the fact that in many Germanic languages, including Standard Yiddish, words in the diminutive form are neuter. Indeed some of the examples that are provided fit this idea; for example, der tish 'the table' is masculine in Standard Yiddish, but dos benk- $l_{D I M}$ 'the chair' is neuter. However, there are also examples that expand the conceptual basis of the rule in surprising ways, such as der boym 'the tree' (masculine in Standard Yiddish) versus dos blum 'the flower' (feminine in Standard Yiddish). ${ }^{20}$ This formulation of course gives no indication of what the accusative or dative forms are, or when they should be used.

There were also speakers who seemed to be aware that written Yiddish and older forms of the language did have gender, but would state that they are no longer sure what the forms should be (e.g., Informant: "Upon reflection you would write di car and dos tish." Researcher: "Not der tish?" Informant: "Hmm, both sound right."). Yet other informants adamantly denied the existence of gender in the language, citing how Yiddish (i.e., the Hasidic Yiddish variety they speak) has no such thing: "It is not like French or Hebrew", they said. Overall, a representative reaction was that speakers were somewhat defensive about this topic. They often felt like their speech was lacking in something that ought to be there. In other words, they had some knowledge of what used to be part of the language, but what is increasingly, or if we are correct, completely absent, and this made them feel self-conscious about their language use.

\subsection{Conclusions}

To summarise, multiple sociolinguistic, historical, and language-internal factors seem to be at play in the substantial development that has taken place in contemporary spoken and written Yiddish in the Stamford Hill Hasidic community since World War II. We have provided evidence that, unlike Standard and pre-War varieties, morphological case and gender are now completely absent in Stamford Hill Hasidic Yiddish. This development, and in particular the loss of case, would suggest that the language has changed its typological character in significant ways.

\footnotetext{
${ }^{20}$ Hotsa'at Chay $(1999,34)$ also states that semantically male entities (people and animals) should be marked with דער der, while female ones should be marked with 1 . In addition, it instructs that words from Hebrew and Aramaic should follow their original genders; for example, words ending in $\mathrm{n}$ should be marked with די דidi. Again, this ignores the concept of case completely.
} 
Our central argument is that Stamford Hill Hasidic Yiddish lacks morphological case and gender. We are not the first to note a tendency towards impoverished case and gender paradigms in Hasidic varieties of Yiddish. Krogh (2012) studied published written data from the Satmar Hasidic community in the United States. He interprets his findings as evidence that "gender and case syncretism [...] has been generalised to the entire paradigm of determiners and to all attributive adjectives" (495). Sadock and Masor $(2018,104)$ put forward a similar description of Bobover Hasidic Yiddish, although they "prefer to frame this as a unification of morphological forms rather than "uncertainty" or "loss". Assouline (2014, 42) similarly describes her findings as "morphological simplifications" in the nominal declension in Israeli Hasidic Yiddish.

However, we believe that the evidence from the Stamford Hill Hasidic community supports a more substantial level of change than morphological case and gender syncretism, a unification of morphological forms, or a simplification of morphological paradigms. First, we propose that the notion of grammatical gender on full nominals is no longer part of the mental grammar of Hasidic Yiddish speakers from the Stamford Hill community. Second, we argue that there is no morphological case on full nominals in this variety. Case distinctions are only consistently marked on pronouns, and thus this aspect of the grammar resembles languages that are recognised not to have morphological case, such as Modern English.

Our work in progress on the absence of morphological case and gender in the spoken and written Yiddish used in Hasidic communities in Israel, Montreal, and Antwerp (Belk, Kahn, and Szendröi [under review 2]) indicates that the same process discussed in this paper is applicable to Hasidic Yiddish more generally. Our findings are further supported by the Satmar Hasidic data from Krogh's work, the Bobover Hasidic data from Sadock and Masor, and the Israeli Hasidic Yiddish data from Assouline's work. In our view, this makes a strong case for positing a separate variety of Yiddish, Hasidic Yiddish, which has characteristics that are substantially different from both Standard Yiddish and the pre-War spoken Yiddish dialects and would therefore warrant the distinction. If the various Yiddish speaking communities throughout the Hasidic world consistently lack morphological gender and case, it would demonstrate that Hasidic Yiddish has a large enough degree of uniformity to be treated as an entity worthy of recognition and further linguistic analysis.

Acknowledgements We would like to thank our research assistants and informants Shifra Hiley, Izzy Posen, and Eli Benedict for all the hard work they do for the project and for their insightful inputs. We thank our expert advisors Mendy Cahan, the director of the YUNG YiDiSH Library and Cultural Centre, and Shmuel Hiley for numerous long conversations about Yiddish and for sharing their deep understanding of Hasidic culture. Without their intellectual contribution and practical help, this research would not have been possible. We thank Ádám Nádasdy, Ad Neeleman, Sonya Yampolskaya, and the audience at the conference on Yiddish Language Structures 2 (11-13 June 2019, University of Düsseldorf, Germany). We thank our participants for their humbling openness and generosity towards us and our research. Last but not least, we thank our three anonymous reviewers for the detailed and constructive comments that helped us improve the paper. All remaining errors and omissions are ours. Szendrôi wishes to gratefully acknowledge the financial support of the British Academy (No. SG162659). 
Open Access This article is licensed under a Creative Commons Attribution 4.0 International License, which permits use, sharing, adaptation, distribution and reproduction in any medium or format, as long as you give appropriate credit to the original author(s) and the source, provide a link to the Creative Commons licence, and indicate if changes were made. The images or other third party material in this article are included in the article's Creative Commons licence, unless indicated otherwise in a credit line to the material. If material is not included in the article's Creative Commons licence and your intended use is not permitted by statutory regulation or exceeds the permitted use, you will need to obtain permission directly from the copyright holder. To view a copy of this licence, visit http:// creativecommons.org/licenses/by/4.0/.

\section{Appendix: Examples}

Table 1 is repeated here with the addition of Hebrew script, as Table 1'.

Table 1' Nominal case and gender marking in Standard Yiddish

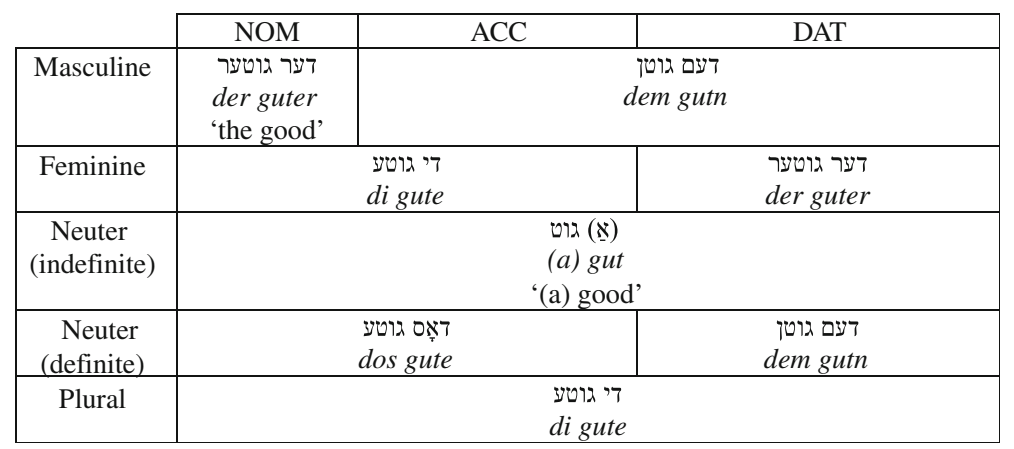

(1') Masculine nominative

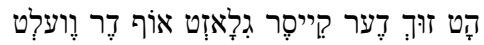

hot zikh der keyser gelozt af der velt

has REFL the.M.NOM emperor let into the.F.DAT world

'the emperor went out into the world' (Nahman of Braslav 1815, 15)

(2') Feminine nominative

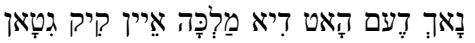

nokh dem hot di malke eyn kuk geton

after that.N.DAT has the.F.NOM queen one look made

'after that the queen took a look' (Nahman of Braslav 1815, 12) 
(3') Neuter nominative

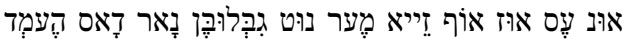

un es iz af zey mer nit geblibn, nor dos hemd

and it is on them more not remained except the.N.NOM shirt

'and nothing more remained on them, except their shirt'

(Nahman of Braslav 1815, 21)

(4') Masculine nominative

\begin{tabular}{llllll}
\hline a. & ler hut & gevist & az & der & $\chi \varepsilon$ Irem iz ni $\mathrm{t}$ gere $\mathrm{t}^{21}$ \\
er hot gevust & az & der & khayrem iz nisht gerekht \\
he has known & that & the.M.NOM ban & is not right
\end{tabular}

'he knew that the ban was wrong' (N. T. Halberstam 07:28)

b. /siz a Sreklexer matsev/

s'iz a shreklekher matsev

it.is a terrible-M.NOM situation

'it's a terrible situation'

(N. T. Halberstam 06:34)

(5') Feminine nominative

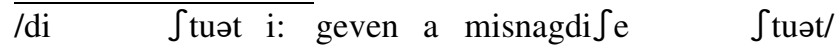

di shtot iz geven a misnagdishe shtot

the.F.NOM town is been a mitnaggedic-F.NOM town

'the town was a mitnaggedic town'

(N.T. Halberstam 08:58)

(6') Neuter nominative/accusative
a. /dus er $\int \mathrm{te} \mathrm{mul} /$
dos ershte mol
the.N.ACC first-N.ACC time
'the first time'
b. /a halb yuər/
a halb yor
a half.N.ACC year
'half a year'

(Teitelbaum, track 1:1, 09:05)

(Y. Y. Halberstam, track 10, 04:22)

\footnotetext{
${ }^{21}$ Realization of the Hebrew letter $\urcorner$ reysh, varies between an apical and a uvular trill. We represent this phoneme with the symbol $/ \mathrm{r} /$. 
(7') Masculine nominative

a. דער גרויסער חכם

der groyser khokhem

the.N.NOM great-N.NOM wise man

'the great wise man'

(Cahan 1992: 64)

b. וואס איז דער גרויסער טומעל

vos iz der groyser tuml?

what is the.N.NOM big-N.NOM commotion

'what's the big commotion?'

(Cahan 1992, 64)

דאס איז פאר די עלטערן די גרעסטע סחורה ('8)

dos iz far di eltern di greste skhoyre

that is for the.PL parents the.F.NOM biggest-F.NOM merchandise(F)

'That is the best thing the parents can want.'

(9') Neuter nominative

אין שטוט איז גיווארין א גרויס גיטימעל

in shtut iz gevorn a groys getiml

in town is became a big.N.NOM/ACC/DAT commotion

'there was a great commotion in [the] town'

(Cahan 1992, 64)

(10') Masculine nominative

\begin{tabular}{llllll}
\hline$/ \mathbf{d} \varepsilon$ & brid-i & & gievejn & a & komunist $/^{22}$ \\
der & bruder & iz & geven & a & komunist \\
the.M.NOM & brother $(M)$ & is & been & a & communist
\end{tabular}

'My (lit: the) brother was a communist.'

(Geller 2001, 206-207)

(11') Feminine nominative

\begin{tabular}{llll}
\hline /ven di & mixume & iz & aro:s/ \\
ven di & milkhome & iz & aroys \\
when the.F.NOM/ACC & war(F) & is & out \\
'when the war broke out' & &
\end{tabular}

(Geller 2001, 158-159)

$\left(12^{\prime}\right)$ a. Neuter nominative (definite)

/dis kint is do- defit gievor/

dos kind iz do dershtikt gevorn

the.N.NOM/ACC $\operatorname{child}(N)$ is here suffocated become

'My (lit: the) child was suffocated here.' (Geller 2001, 306-307)

\footnotetext{
22 Phonetic transcriptions of the data from Geller 2001 are taken from that work. Geller's barred small capital $\mathrm{I}$ is here rendered as a barred i.
} 
b. Neuter nominative (indefinite)

\begin{tabular}{|c|c|c|c|}
\hline $\begin{array}{l}\text { /ausstralje } \\
\text { oystralye }\end{array}$ & 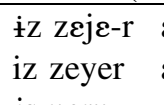 & $\begin{array}{ll}\text { a } & \text { J'ajn } \\
\text { a } & \text { sheyn }\end{array}$ & $\begin{array}{l}\text { land/ } \\
\text { land }\end{array}$ \\
\hline Australia & is very & a beautiful.N.IND & country $(N)$ \\
\hline
\end{tabular}

'Australia is a very beautiful country.'

(Geller 2001, 194-195)

(13') a. /də houz iz grois/ *groise/

De hoyz iz groys/ *groyse

the house is big/ big-E

'The house is big.'

b. /frayhayt iz vi $\chi$ tig/ *vi $\chi$ tige/

Frayhayt iz vikhtig/ *vikhtige.

freedom is important/ important-E

'Freedom is important.'

דאס שייכות צווישן דאס ידיש פאלק און ירושלים איז אן אייביגער ('14)

dos shaykhes tsvishn dos yidish folk un yerushalayim

the.N.NOM connection $(\mathrm{N})$ between the.N.NOM Jewish people $(\mathrm{N})$ and Jerusalem

iz an aybiger

is an eternal-M.NOM

'The connection between the Jewish people and Jerusalem is an eternal one.'

Jewish Tribune 2017b

צו פארלייכטערן די עקאנאמישע צושטאנד aykhte

tsu farlaykhtern di ekonomishe tsushtand

to relieve the.F.NOM/ACC economic-F.NOM/ACC condition(M)

'to relieve the economic condition' Jewish Tribune 2017b

b. דער ערשטער אפטיילונג איז געווען

der ershter opteylung iz geven...

the.M.NOM first-M.NOM section $(F)$ is been

the first section was... Jewish Tribune 2017a 
דער בריטישער פרעמיער מיניסטארשע טעריסא מיי האט געליטן א נידערלאגע אין די בריטישע וואלן וואלן

$\begin{array}{lllll}\text { der } & \text { britisher } & \text { premier } & \text { ministorshe } & \text { terisa } \\ \text { the.M.NOM } & \text { British-M.NOM } & \text { prime } & \text { minister-F } & \text { Theresa } \\ \text { mey } & \text { hot gelitn } & \text { a } & \text { niderlage } & \\ \text { May } & \text { has suffered } & a & \text { defeat } & \end{array}$

in di britishe valn

in the.PL British-PL elections

'The British prime minister Theresa May has suffered a defeat in the British elections.'

Jewish Tribune 2017c

b. לכבוד דער איבערגעגעבענ מנהל

lekoved der ibergegebene menahel

in.honour.of the.F.DAT devoted-F.NOM/ACC director(M)

'in honour of the devoted director'

Jewish Tribune 2017e

בריטישע פרעמיער מיניסטארשע פארלירט מערהייט ביי וואלן ('17)

britishe premier ministorshe farlirt merhayt bay valn

British-F.NOM/ACC prime minister-F loses majority at elections

'British Prime Minister loses majority in election' Jewish Tribune 2017c

ביי די כותל המערבי ay')

$\begin{array}{llll}\text { bay } & \text { di } & \text { koysel ha-marovi } \\ \text { at } & \text { the.F.NOM/ACC } & \text { wall the-western }\end{array}$

'at the Western Wall'

Jewish Tribune 2017b

b. צום כותל המערבי

tsum koysel ha-marovi

to.THE.M/N.DAT wall the-western

'to the Western Wall'

Jewish Tribune 2017b

צו עפענען א גרויסע שימחה-זאל a.

tsu efenen a groyse simkhe-zal

to open a large-F.NOM/ACC celebration-hall

'to open a large celebration hall' Jewish Tribune 2017a

b. א דינער אינעם מרים רחל וואהל זאל

a diner inem miryem rokhl vohl zal

a dinner in.the.M/N.DAT Miriam Rachel Wohl hall

'a dinner in the Miriam Rachel Wohl Hall' Jewish Tribune 2017a

די גאנצע הויז נומער 187 איז איבערגעארבעט געווארן

di gantse hoyz numer $187 \mathrm{iz}$ ibergearbet gevorn

the.F.NOM/ACC whole-F.NOM/ACC house number 187 is over.worked become

'the whole of house number 187 was remodelled' Jewish Tribune 2017a

b. האט מען אפגעקויפט דעם דערנעבנדיגן הויז

hot men opgekoyft dem dernebndign hoyz

have one up.bought the.M.ACC nearby-M.ACC house

'they bought up the nearby house'

Jewish Tribune 2017a 
(21') Masculine accusative

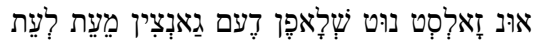

un zolst nit shlofn dem gantsn mes-les

and should not to.sleep the.M.ACC whole-м.ACC 24-hour.period(м)

'and you must not sleep the whole day and night' (Nahman of Braslav 1815, 12)

(22') Masculine dative

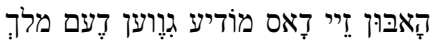

hobn zey dos moydiye geven dem meylekh

have they the.N.NOM inform were the.M.DAT king(M)

'they informed the king of it' (Nahman of Braslav 1815, 11)

(23') Feminine accusative

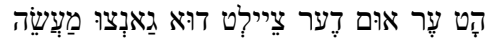

hot er im dertseylt di gantse mayse

has he him told the.F.ACC whole-F.ACC story $(F)$

'so he told him the whole story' (Nahman of Braslav 1815, 13)

(24') Feminine dative

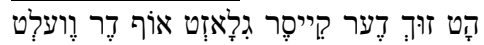

hot zikh der keyser gelozt af der velt

has REFL the.M.NOM emperor let into the.F.DAT world(F)

'the emperor went out into the world' (Nahman of Braslav 1815, 15)

(25') Neuter accusative

אַז עֶר זָָָל אוּם וַוייזוּן דָאס אוֹרְט

az er zol im vayzn dos ort

that he should him to.show the.N.ACC place(N)

'for him to show him the place' (Nahman of Braslav 1815, 64)

(26') Neuter dative

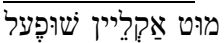

mit a kleyn shifl

with a small.N.DAT boat.DIM(M)

'with a small boat'

(Nahman of Braslav 1815, 18) 
(27') Masculine accusative

a. /haltn dem yontef/
haltn dem yontef
to.keep the.M.ACC festival(M)
'to keep the festival'

b. /tsi Seltn dem

tsu sheltn dem

harlikn

(Teitelbaum, track 1:1, 04:03)

to to.curse the.M.ACC holy-M.ACC

guen/

goen

'to curse the holy Gaon'

c. I $\chi$ vars di hust

a gantsn tug nist gelernt/

kh'veys du host a gantsn tog nisht gelernt

I.know you.SG have a whole-M.ACC $\operatorname{day}(\mathrm{M})$ not learnt

'I know you haven't studied [Torah] all day.'

(Y. Y. Halberstam, track 6, 04:36)

(28') Masculine dative

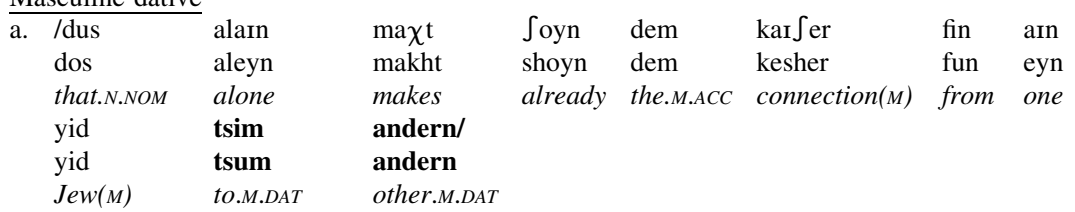

'That alone is enough to make the connection from one Jew to the other.'
b. /ofn gantsn gif/
oyfn gantsn guf
on.the.m.DAT whole-M.DAT body(M)
'on his (lit: the) whole body'

(Y. Y. Halberstam, track 10, 06:54)

(29') Feminine accusative

\begin{tabular}{lllll}
\hline /husti & gemaxt & yeıde & halbe & shuə/ \\
hostu & gemakht & yede & halbe & sho \\
have.you & made & every-F.ACC & half-F.ACC & hour $(F)$
\end{tabular}

'you did [it] every half an hour' (Y. Y. Halberstam, track 6, 04:48)

$\left(30^{\prime}\right)$ Feminine dative

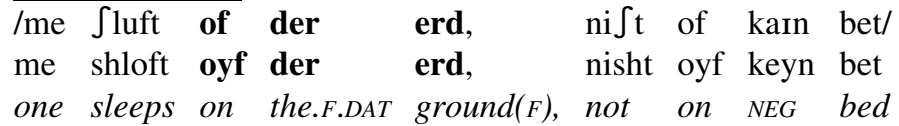

'they sleep on the ground, not in a bed' (Y. Y. Halberstam, track 2, 01:31)

(31') Neuter dative

\begin{tabular}{llll}
\hline /mit & a & grols & $\mathbf{k o l} /$ \\
mit & a & groys & kol \\
with & a & big.N.DAT & voice $(N)$
\end{tabular}

'with a loud voice'

(N. T. Halberstam 00:08) 
(32') Masculine accusative

דער קויפער נעמט שנעל דעם אוצר

der koyfer nemt shnel dem oytser

the.м.NOM buyer(M) takes quickly the.м.ACC treasure(м)

'The buyer quickly takes the treasure.'

(Cahan 1992, 68)

(33') Masculine dative

a. רופט זיך אן איינער צום צווייטין

ruft zikh on eyner tsum tsveytn

calls REFL out one-M.NOM to.M.DAT second-M.DAT

'One calls out to the other.' (Cahan 1992, 65)

b. פון דעם פרעמדין גאסט

fun dem fremdn gast

from the.M.DAT strange-M.DAT guest(M)

'from the strange guest'

(Cahan 1992, 69)

(34') Feminine accusative

גייענדיג שוין א לאנגע צייט צו פוס

geyendik shoyn a lange tsayt tsu fus

going already a long-F.ACC time(F) on foot

'having walked on foot for a long time'

(Cahan 1992, 65)

(35') Feminine dative

אין דער גרויסער שוהל

in der groyser shul

in the.F.DAT big-F.DAT synagogue(F)

'in the big synagogue'

(Cahan 1992, 64)

(36') Neuter accusative

a. און מען האט אב גימאכט דאס גישעפט

un men hot opgemakht dos gesheft

and one has made the.N.ACC deal

'and they made the deal' (Cahan 1992, 65)

b. מען דערלאנגט דיר דאָס שענסטע און בעסטע עססין

men derlangt dir dos shenste un

one gives you.DAT.SG the.N.ACC beautiful-most-N.ACC and

beste esn

best-N.ACC food $(N)$

'They give you the most delicious and best food.' (Cahan 1992, 66) 
(37') Neuter dative

אין א האלב יאר

$\begin{array}{llll}\text { in } \quad \text { a } & \text { halb } & \text { yor } \\ \text { in a } & \text { half.N.DAT } & \text { year }(N) \\ \text { 'in half a year' } & \end{array}$

(Cahan 1992, 65)

b. צוויי האלצהעקער פון א קליין דערפיל

tsvey holtsheker fun a kleyn derfl

two woodcutter from a small.N.DAT village( $N$ )

'two woodcutters from a small village'

(Cahan 1992, 65)

$\left(38^{\prime}\right)$
a. /ba de na $\quad \mathrm{d}$ /
bay
der
nakht
by
the.F.DAT night
'at night'
t/
b. /ba di
$\mathrm{di} \quad$ na $\chi^{\mathrm{t} /}$
bay di
nakht
by the.F.NOM/ACC night
'at night'

(Geller 2001, 292-293)

$\left(39^{\prime}\right)$

a. /

jejangie mi-

[ikh bin] gegangen mit

[I am] went with

'I went with my (lit: the) stepmother).'

(Geller 2001, 306-307)
b. $/ \mathrm{m}$ - ot
gic...skarzet farn
me hot
ge... skarzhet farn
one has
told.on
before.the.M.DAT father.M.DAT
'Someone told on me to my (lit:the) father.' (Geller 2001, 234-235)

$\mathrm{d} \dot{\mathbf{m}} \quad$ Stifmamen/
di
shtifmamen

the.F.NOM/ACC/DAT stepmother.DAT

(Geller 2001, 232-233)

דעם צווייטן טייל האט אנטהאלטן וואונטשן a.'

dem tsveytn teyl hot anthaltn vuntshn

the.M.ACC/DAT second-M.ACC/DAT part has contained wishes

'The second part contained wishes...' Jewish Tribune 2017a

b. דער פרעזידענט האט דינסטאג אפגעהאלטן זיין רעדע צי דאס פאלק

der prezident hot dinstog ofgehaltn zayn rede

the.м.Nом president has Tuesday held his speech

tsu dos folk...

to the.N.NOM/ACC people

'The president gave his speech to the people on Tuesday.'

Jewish Tribune 2017b 
$\left(41^{\prime}\right)$

a.

ווערט געזען דער אידישע איידעם

vert gezen der

idishe eydem

becomes seen the.M.NOM

Jewish-F.NOM/ACC son-in-law

'the Jewish son-in-law can be seen'

Jewish Tribune 2017b

b. אויף דער לינקע זייט

$\begin{array}{llll}\text { oyf } & \text { der } & \text { linke } & \text { zayt } \\ \text { on } & \text { the.M.NOM } & \text { left-F.NOM/ACC } & \text { side }\end{array}$

'on the left side'

Jewish Tribune 2017b

\section{References}

Allen, Cynthia L. 1997. Middle English case loss and the 'creolization' hypothesis. English Language and Linguistics 1 (1): 63-89.

Assouline, Dalit. 2014. Language change in a bilingual community: The preposition far in Israeli Haredi Yiddish. In Yiddish language structures, ed. Marion Aptroot and Björn Hansen, 39-62. Berlin: De Gruyter Mouton.

Assouline, Dalit. 2017. Contact and ideology in a multilingual community: Yiddish and Hebrew among the Ultra-Orthodox. Berlin: Mouton De Gruyter.

Assouline, Dalit. 2019. Subordination in American and Israeli Haredi Yiddish. Paper presented at YiLaS 2, University of Düsseldorf, 11-13 June 2019.

Bates, Elizabeth, Angela D. Friederici, and Brian Wulfeck. 1987. Grammatical morphology in aphasia: Evidence from three languages. Cortex 24 (3): 545-574.

Biale, David, et al. 2018. Hasidism: A new history. Princeton: Princeton University Press.

Beinfeld, Solon, and Harry Bochner (eds.). 2013. Comprehensive Yiddish-English dictionary. Bloomington: Indiana University Press.

Belk, Zoë, Lily Kahn, and Kriszta Eszter Szendrői. Under review 1. The loshn koydesh component in contemporary Hasidic Yiddish. Journal of Jewish Languages.

Belk, Zoë, Lily Kahn, and Kriszta Eszter Szendrői. Under review 2. Absence of morphologicla case and gender marking in contemporary Hasidic Yiddish worldwide. Journal of Germanic Linguistics.

Belk, Zoë, Lily Kahn, Kriszta Eszter Szendrői, and Sonya Yampolskaya. In prep. Innovations in the Hasidic Yiddish pronominal system. In Linguistic contact with minoritized and diaspora languages of Europe. Berlin: Language Science Press.

Cahan, Meier. 1992. Unpublished writings. Ms, Antwerp.

Catalogue of endangered languages. 2018. Eastern Yiddish. http://www.endangeredlanguages.com/lang/ 3211. Accessed 14 Aug 2019.

Doron, Edit, and Irit Meir. 2015. The impact of contact languages on the degrammaticalization of the Hebrew definite article. Journal of Jewish Languages 3 (1-2): 283-299.

Ferré, Christa Barbara Meister. 1991. Stability and change in the Pennsylvania German dialect of an Old Order Amish community in Lancaster County. PhD dissertation, University of Georgia.

Finkel, Raphael. n.d. רפּאל פַינקלס אַנליִין ווערטערבוך [Raphael Finkel's Online Dictionary]. https://www.cs. uky.edu/raphael/yiddish/dictionary.cgi. Accessed 20 Oct 2019.

Geller, Ewa. 2001. Warschauer Jiddisch. Berlin: De Gruyter.

Hotsa'at Chay. 1999. שרייב עם ריכטיג. די אידישע פארשריפט [Yiddish writing. Write it correctly]. New York: Ohel Printers.

Holman, Christine, and Naomi Holman. 2002. Torah, worship and acts of loving kindness: Baseline indicators for the Charedi community in Stamford Hill. Leicester: De Montfort University.

Huffines, Marion Lois. 1989. Case usage among the Pennsylvania German sectarians and nonsectarians. In Investigating obsolescence: Studies in language contraction and death, ed. Nancy Dorian, 211226. Cambridge: Cambridge University Press.

Isaacs, Miriam. 1999. Contentious partners: Yiddish and Hebrew in Haredi Israel. International Journal of the Sociology of Language 138: 101-121. 
Isurin, Ludmila, and Tanya Ivanova-Sullivan. 2008. Lost in between: The case of Russian heritage speakers. Heritage Language Journal 6: 72-104.

Jacobs, Neil G. 1990. Northeastern Yiddish gender-switch: Abstracting dialect features regionally. Diachronica 7 (1): 69-100.

Jacobs, Neil G. 2005. Yiddish: A linguistic introduction. Cambridge: Cambridge University Press.

Jewish Tribune. 2017a. בית המדרש כנסת יחזקאל פייערט 30 יאהר זינט איהר גרינדונג [Study house Kneses Yekhezkel celebrates 30 years since its establishment].

Jewish Tribune. 2017b. אמעריקאנער פרעזידענט טראמפ באזוכט אין מדינת ישראל [American president Trump visits Israel].

Jewish Tribune. 2017c. בריטישע פרעמיער מיניסטארשע פארלירט מערהייט ביי וואלן [British prime minister loses majority in elections].

Jewish Tribune. 2017d. פרעמיער מיניסטארשע מיי שליסט אפמאך מיט איירישע פארטיי [Prime minister May makes agreement with Irish party].

Jewish Tribune. 2017e. מסיבת פרידה פאר מנהל פון פרדס [Leaving party for director of Pardes].

Kahn, Lily. 2009. The verbal system in late Enlightenment Hebrew. Leiden: Brill.

Kahn, Lily. 2015. A grammar of the Eastern European Hasidic Hebrew tale. Leiden: Brill.

Katz, Dovid. 1987. Grammar of the Yiddish language. London: Duckworth.

Kester, Ellen-Petra. 1996. The nature of adjectival inflection. PhD dissertation, Utrecht University.

Khramova, Maria. 2011. The Volga German dialect of Milberger, Kansas. PhD dissertation, University of Kansas.

Korecky-Kröll, Katharina, and Wolfgang U. Dressler. 2009. The acquisition of number and case in Austrian German nouns. In Development of nominal inflection in first language acquisition: A crosslinguistic perspective, ed. Ursula Stephany and Maria D. Voeikova, 265-302. Berlin: de Gruyter.

Krogh, Steffen. 2012. How Satmarish is Haredi Satmar Yiddish? In Leket: Yiddish studies today, ed. Marion Aptroot, M. Aptroot, et al., 483-506. Düsseldorf: Düsseldorf University Press.

Krogh, Steffen. 2018. How Yiddish is Haredi Satmar Yiddish? Journal of Jewish Languages 6 (1): 5-42.

Language and culture atlas of Ashkenazic Jewry. https://library.columbia.edu/locations/global/jewish studies/lcaaj.html. Accessed 14 Aug 2019.

Luzzatti, Claudio, and Ria De Bleser. 1999. Gender and number inflectional morphology in Italian agrammatic speakers: Further evidence for dual route models of processing. Rivista di Linguistica 11 (1): 103-131.

Martinez-Gibson, Elizabeth. 2011. A comparative study on gender agreement errors in the spoken Spanish of heritage speakers and second language learners. Porta Linguarum 15: 177-193.

Mitchell, Bruce. 2006. Language politics and language survival: Yiddish among the Haredim in post-War Britain. Leuven: Peeters.

Nahman of Braslav. 1815. סיפורי מעשיות [The Tales of Nahman of Braslav]. Repr., New York.

Nove, Chaya. 2018. The erasure of Hasidic Yiddish from 20th-century Yiddish linguistics. Journal of Jewish Languages 6 (1): 111-143.

Polinsky, Maria. 2008. Gender under incomplete acquisition: Heritage speakers' knowledge of noun categorization. Heritage Language Journal 6 (1): 40-71.

Polinsky, Maria. 2011. Reanalysis in adult heritage language: A case for attrition. Studies in Second Language Acquisition 33: 305-328.

Sadock, Benjamin, and Alyssa Masor. 2018. Bobover Yiddish: "Polish" or "Hungarian?". Journal of Jewish Languages 6 (1): 89-110.

Schmid, Monika S. 2002. First language attrition, use and maintenance: The case of German Jews in Anglophone countries. Amsterdam: John Benjamins.

Schmid, Monika S. 2013. First language attrition. Linguistic Approaches to Bilingualism 3 (1): $94-115$.

Stolberg, Doris. 2015. Changes between the lines: Diachronic contact phenomena in written Pennsylvania German. Berlin: De Gruyter.

Swadesh, Morris. 1971. The origin and diversification of language. Ed. by Joel Sherzer. Chicago: Aldine.

Trudgill, Peter. 1986. Dialects in contact. Oxford: Blackwell.

Wallmannsberger, Josef. 1988. The 'creole hypothesis' in the history of English. In Historical English: On the occasion of Karl Brunner's 100th birthday, ed. Manfred Markus, 19-36. Innsbruck: Institut fur Anglistik.

Weinreich, Uriel. 2007. Yiddish language. In Michael Berenbaum and Fred Skolnik, vol. 21, 2nd ed, ed. Encyclopaedia Judaica, 332-338. Detroit: Macmillan Reference USA. 
Wolf, Meyer. 1969. The geography of Yiddish case and gender variation. In The field of Yiddish: Studies in language, folklore and literature, 3rd collection, ed. Marvin I. Herzog, Wita Ravid, and Uriel Weinreich, 102-215. The Hague: Mouton.

YIVO Institute for Jewish Research. 2019. Yiddish alef-beys (alphabet): https://www.yivo.org/YiddishAlphabet. Accessed 2 Nov 2019.

\section{Audio recordings}

Halberstam, Naftali Tzvi., n.d. ספורי צדיקים [Stories of righteous men].

Halberstam, Yekutiel Yehudah. 1983. תורה - יסוד היהדות [Torah-The foundation of Judaism].

Teitelbaum, Joel. 1949. דברות קודש לחנוכה, חלק א. יסות [Holy words for Chanukkah, part 1].

Publisher's Note Springer Nature remains neutral with regard to jurisdictional claims in published maps and institutional affiliations. 